Document downloaded from:

http://hdl.handle.net/10251/108342

This paper must be cited as:

Montalbán-Domingo, L.; García-Segura, T.; Sanz-Benlloch, MA.; Pellicer, E. (2018). Social sustainability criteria in public-work procurement: An international perspective. Journal of Cleaner Production. 198:1355-1371. doi:10.1016/j.jclepro.2018.07.083

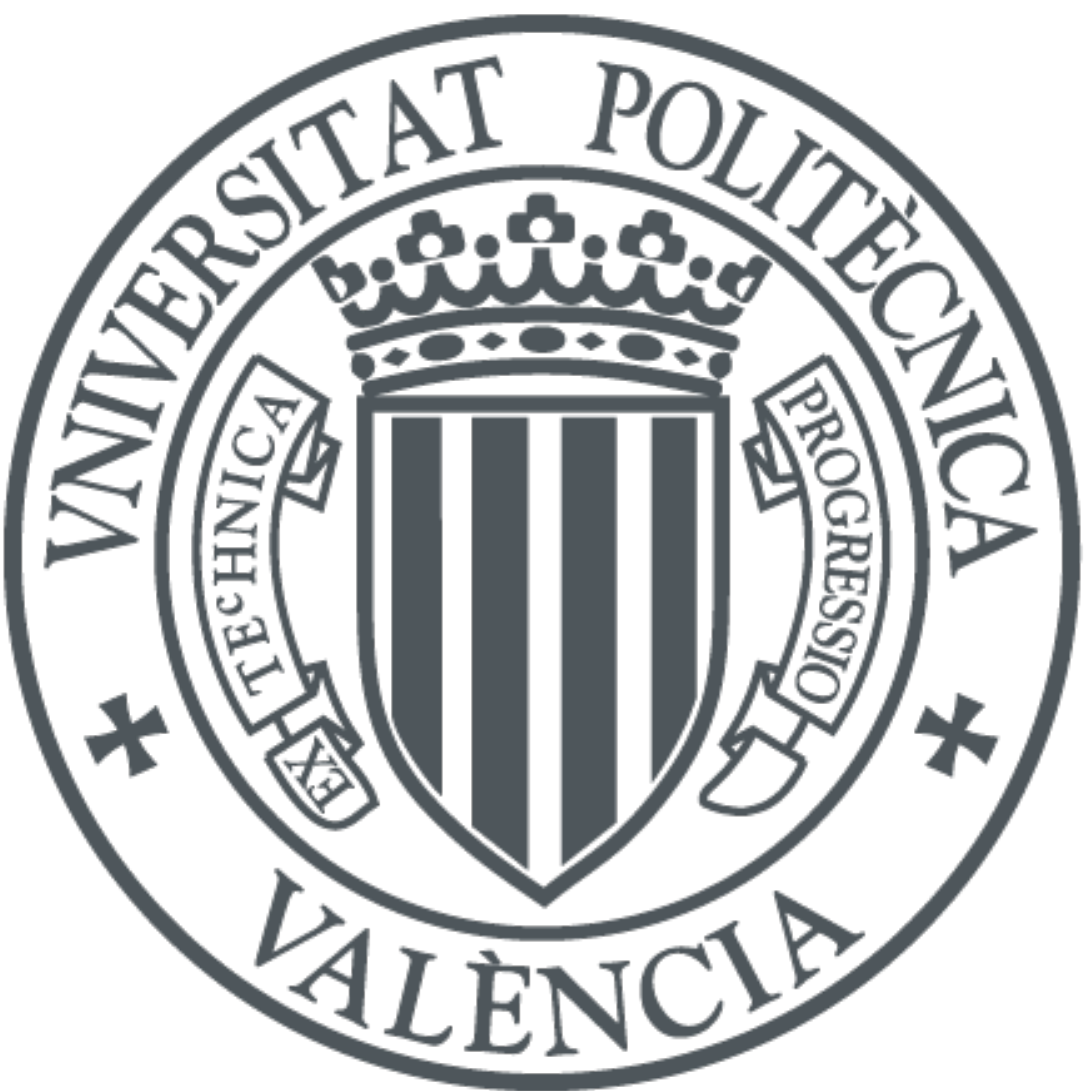

The final publication is available at

https://doi.org/10.1016/j.jclepro.2018.07.083

Copyright Elsevier

Additional Information 


\title{
Social Sustainability Criteria in Public-Work Procurement: An International Perspective
}

\author{
Laura Montalbán-Domingo ${ }^{1}$, Tatiana García-Segura ${ }^{2}$, M. Amalia Sanz ${ }^{3}$, Eugenio Pellicer ${ }^{4}$
}

\begin{abstract}
Scientific literature highlights the need to engage social sustainability more effectively in the construction industry through public procurement. Previous contributions have been focused on establishing strategies and defining guides to encourage and facilitate the inclusion of social criteria in public procurement. However, to reach effective results, the characterization of the current scenario needs to be clarified. With this aim, this research analyzes 451 tendering documents from 10 countries in terms of social sustainability. Three research questions are stated to characterize what the current main social criteria are, how these are defined, and what the differences and similarities are with respect to the inclusion of social criteria in tendering procedures at the international level. To analyze tendering documents, a quantitative content analysis that combines inductive and deductive approaches is developed. Descriptive statistics and statistical analysis based on correspondence analysis and the chi-square contingency table analysis are performed. The results show a lack of metrics to assess social sustainability objectively, the predominance of health and safety as the main social criteria that are included in public procurement, and the importance of the contract size in the number of social categories considered in procurement procedures. However, the main result of this research is focused on showing the important role that the variable "country" plays when the behavior regarding the inclusion of social sustainability is compared at the international level since significant differences are found between Anglo-Saxon and Spanish-speaking countries. Policies should be implemented to promote the use of social criteria and metrics in the award of projects and in the evaluation and monitoring of social performance in the construction industry.
\end{abstract}

Keywords: sustainability; social sustainability; construction industry; public procurement; content analysis; social criteria.

\section{Introduction}

\subsection{Problem Statement}

The construction industry is a crucial sector for the economic development of countries. This sector is strongly associated with regional and national economies (Burke and King, 2015), and it is notably responsible for maintaining stable economic growth and employment and encouraging social progress (Hall and Purchase, 2006). The construction industry has a significant effect on the environment and

\footnotetext{
${ }^{1}$ Assistant Professor, Dept. of Construction Engineering and Civil Engineering Projects, Universitat Politècnica de València, 46022 Valencia, Spain. Corresponding author. Phone +3496387000, Ext:75624; E-mail: laumondo@upv.es

${ }^{2}$ Assistant Professor, Dept. of Construction Engineering and Civil Engineering Projects, Universitat Politècnica de València, 46022 Valencia, Spain. E-mail: tagarse@upv.es

${ }^{3}$ Associate Professor, Dept. of Construction Engineering and Civil Engineering Projects, Universitat Politècnica de València, Camino de Vera s/n, 46022 Valencia, Spain. E-mail: asanz@cst.upv.es

${ }^{4}$ Associate Professor, Dept. of Construction Engineering and Civil Engineering Projects, Universitat Politècnica de València, Camino de Vera s/n, 46022 Valencia, Spain. E-mail: pellicer@upv.es
} 
society. However, numerous authors have stated that it is under-performing in each of the key sustainability dimensions: environmental, social, and economic (Bratt et al., 2013; Kahlenborn et al., 2010; Myers, 2013; Tsai and Chang, 2012), and the role of public procurement have been claimed to drive the integration of sustainability initiatives into construction practices (Adetunji et al., 2003; Brown et al., 2012; Sierra et al., 2018a; Walker et al., 2012).

To encourage sustainability in public procurement, environmental and social policies have been implemented in many countries around the world (Andrecka, 2017). Procurers are fostered to include both social and environmental criteria in tendering procedures to guarantee a sustainable performance during the infrastructure life cycle, ensuring respect for social needs and developing sustainable practices that minimize environmental impact, optimize natural resources, encourage using recycled materials, and minimize generation of waste (Testa et al., 2016a). However, important barriers hinder the effective and efficient implementation of sustainability in construction public procurement (Sourani and Sohail, 2011; Testa et al., 2016a; Walker and Brammer, 2009). Although these barriers can be different for each country due to socio-economic, demographic, and cultural aspects (Adham and Siwar, 2012), recent studies highlight that the main barriers affecting the correct implementation of sustainable construction procurement are the lack of knowledge about how to consider sustainability criteria in procurement procedures (Carter and Fortune, 2007; Testa et al., 2016b) and the lack of objective methods to assess (Ruparathna and Hewage, 2015) and monitor these sustainability criteria (Wright, 2015). These facts are aggravated if the analysis is focused on social sustainability (Burke and King, 2015; Pan, 2015; Ruparathna and Hewage, 2015; Sierra et al., 2017).

Social sustainability has been characterized by being a key element in the construction industry, boosting the interaction between stakeholders to address the needs of current and future populations and communities (Valdes-Vasquez and Klotz, 2013). However, one of the major current drawbacks of construction procurement practices is to misinterpret the triple bottom line of sustainability with the social issues underestimated and overshadowed by the environmental dimension. Loosemore (2016) and AbdelRaheem and Ramsbottom (2016) emphasized that there is currently no understanding of what social sustainability means for the construction industry and how it can be engaged more effectively. Thus, this scenario makes the social issues difficult to consider in sustainable construction and, most importantly, makes it difficult to apply them and measure them quantitatively in construction public procurement.

\subsection{Knowledge Gap}

Walker et al. (2012) and Roman (2017) argued that scholars need to do more in terms of analyzing and informing management and professional communities about areas such as public procurement and sustainability and factors encouraging sustainable practices. However, most studies that have analyzed sustainability in construction projects have been specially focused on the environmental aspects rather than the social and economic ones (Abdel-Raheem and Ramsbottom, 2016; Whang and Kim, 2015).

The literature associated with the study of the social dimension in construction public procurement is scarce (Akenroye, 2013; Burkett, 2010; Loosemore, 2016; McCrudden, 2004; Petersen and Kadefors, 2016; Ruparathna and Hewage, 2015). Most of the research that has assessed the inclusion of sustainability criteria in tendering documents of the construction industry has been centered mainly on 
environmental criteria (Faith-Ell et al., 2006; Fuentes-Bargues et al., 2017; Testa et al., 2016b; Xia et al., 2014), and being very limited, the research referred to social criteria (Hueskes et al., 2017; Ruparathna and Hewage, 2015). Moreover, few works are in-depth studies that compare different scenarios (Petersen and Kadefors, 2016) since these have been focused on specific sectors of specific countries (Brammer and Walker, 2011).

Thus, these facts indicate the need to increase the scientific literature that examines, analyzes, and facilitates the effective implementation of social sustainability in construction procurement (AbdelRaheem and Ramsbottom, 2016) and boosts an increase of consideration and practice of social sustainability at the different stages of construction projects. Consequently, a knowledge gap exists regarding 1 ) how social sustainability is considered in the construction industry, 2) the significance of the role played by procurers in institutionalizing sustainable practices in social procurement within the construction industry, and 3) how social procurement policies are implemented and embedded in daily procurement practices among procurement professionals worldwide (McCrudden, 2004; Walker and Brammer, 2012).

\subsection{Research Questions}

To find an answer regarding the identified knowledge gap, this paper aims to analyze the inclusion of the social dimension of sustainability within public procurement in the construction industry at the international level. Thus, this research seeks to analyze what the main social criteria are (Q1) and how these criteria are defined (Q2). Finally, the comparison between countries is assessed to analyze whether significant differences exist with respect to the inclusion of social criteria in tendering procedures (Q3).

\subsection{Organization of the Paper}

The paper is structured as follows. Section 2 presents the literature review about social sustainability in the construction industry. Section 3 describes the research method that defines the data collection and illustrates the research design based on the use of content analysis. By conducting descriptive statistics and a statistical analysis, Section 4 shows the results with respect to the main social criteria considered in the analyzed tendering documents, considering the variability associated with the variable contract size and contract duration and the differences among countries gathered in the sample. Section 5 discusses the main results, considering the three research questions stated previously. Finally, conclusions are presented in Section 6, discerning the contributions, implications for theory and practice, limitations, and future research.

\section{Literature Review}

Though the social contribution of an infrastructure project depends strongly on its interaction with the contextual conditions (Sierra et al., 2018a), authors such as Pocock et al. (2016), Popovic et al. (2018), and UNEP (2009) have highlighted that, in the construction industry, the main benefits associated with the implementation of social sustainability are based on improving the quality of human life, increasing transparency, implementing skill training, and seeking intergenerational equity, fair distribution of construction social costs and capacity enhancement of the disadvantaged. These social benefits can be 
intangible to developers; however, community experts highlight that they are as important as the economic and environmental benefits (Valdes-Vasquez and Klotz, 2013).

The term social sustainability has been in continuous evolution (Valdes-Vasquez and Klotz, 2013). Andrecka (2017) claimed that the concepts of social sustainability and corporate social responsibility are connected in the context of public procurement because they are based on the same topics: labor issues, human rights protection, and ethics issues. Popovic et al. (2018) stated that aspects related to health, safety, human rights, child labor, labor issues, community initiatives, and employment benefits are generally accepted within social sustainability.

Regarding the construction industry, according to Valdes-Vasquez and Klotz (2013), social sustainability has various interpretations depending on the phase of the project life cycle and the stakeholder's perspective. For each perspective, numerous classifications of social criteria can be found in the literature: to estimate the effects associated with the development of construction projects in the planning and design phase (Beiler and Treat, 2015; Khalili-Damghani and Tavana, 2014; Pardo-Bosch and Aguado, 2016; Sierra et al., 2015, 2017; Valdes-Vasquez and Klotz, 2013; Yigitcanlar and Dur, 2010);to assess company performance through corporate social responsibility practices (Rahdari and Anvary Rostamy, 2015) and supplier evaluation procedures (GRI, 2011; Popovic et al., 2018; Sarkis et al., 2012; Winter and Lasch, 2016); to analyze the social life cycle of products and materials along the project life (Hossain et al., 2017; Hosseinijou et al., 2014; UNEP, 2009); and to take part in the decision-making process of designing, constructing, and operating construction projects (CEEQUAL, 2010; FHWA-INVEST, 2012; Harmer et al., 2012; Hong and Ng, 2015; ISI, 2015; Oltean-Dumbrava et al., 2014; Sierra et al., 2017; Sourani, 2008; Ugwu and Haupt, 2007).

However, Sierra et al. (2018b) claimed that the definition of the criteria that should be considered to assess social sustainability in construction projects has not been clearly established, and in many cases, only a limited number of social aspects are considered (Ekener et al., 2018). Consequently, for a deeper investigation into social sustainability, this study reviews the scientific literature, guides, and reports to establish the main groups of social criteria that should be considered in construction tendering documents. Social criteria were grouped using the affinity diagram technique (Carnevalli and Miguel, 2008) into eight categories (or groups of criteria), including cultural heritage, employment, health and safety, local, professional ethics, public participation, training, and users' impact.

Cultural heritage gathers those criteria focused on actions that favor the protection of architectural, archeological, and paleontological resources and tribal cultural properties and the historical, artistic, and civil heritage in the area affected by the projects (Arce and Gullón, 2000; ISI, 2015; UNESCO, 2017). The aim of these criteria is to enforce the feeling of respect toward the communities (Abdel-Raheem and Ramsbottom, 2016) and protect non-renewable cultural resources, which are essential elements for current and future human development (CEEQUAL, 2010). Whang and Kim (2015) and CEEQUAL (2010) highlighted that the development of a cultural heritage appraisal and management plan can be performed to relate the project with existing local cultural values and maintain the heritage value of the existing facility. Moreover, the collaboration with historical or cultural preservationists can be recommended to ensure that works do not damage the quality of the existing historical and/or cultural 
resources (ISI, 2015) and to guarantee the management and inspection of mitigation work (CEEQUAL, 2010).

As Loosemore (2015) highlighted, employment is a key social criteria. In the construction industry, the traditional forms of employment that characterize construction, such as subcontracting and increasing workforce casualization and self-employment, can contribute to social problems. However, through social procurement, employment requirements may have important implications for both procuring organizations and suppliers (Petersen and Kadefors, 2016). McCrudden (2004) stated that public procurement may be the tool to address unemployment through the creation and maintenance of employment and via increasing the labor participation of the long-term unemployed and disadvantaged groups. Authors such as Shiau and Chuen-Yu (2016) and Pellicer et al. (2016) emphasized the enhancement of employment stability to improve sustainable development and to show how the organization structures its human resources to implement its overall strategy and the level of satisfaction among employees (GRI, 2011). Additionally, the European Commission (2010) noted the important role of small and medium enterprises (SMEs) in the economy, and CEEQUAL (2010) mentioned the increase of the relationship with SMEs with a positive effect on the community from an economic perspective.

The construction industry is characterized by competitive processes with a high participation of subcontractors and long supply chains that, along with the ever-changing work environment and harsh working conditions, make it dangerous (Oswald et al., 2018). Having a health and safety committee or expert workers in health and safety during the project can facilitate a positive health and safety culture (Popovic et al., 2018). Additionally, the development of protocols or workplace health and safety management plans is recommended to assess the risks associated with the construction work and the use of new materials, technologies, and/or methodologies (ISI, 2015). Certificates to demonstrate the occupational health and safety performance of companies can improve employee satisfaction, maintain operational processes, and increase the company image (Popovic et al., 2018; Rahdari and Anvary Rostamy, 2015), while promoting and protecting human health through a healthy and safe work environment (Abdel-Raheem and Ramsbottom, 2016). Finally, along project life, public safety needs to be maximized (Kylili et al., 2016; Ugwu and Haupt, 2007).

Encouraging the participation of local companies in construction projects can have direct and indirect benefits for the community (CEEQUAL, 2010). In addition to the creation of direct jobs and the payment of wages and taxes, GRI (2011) and Abdel-Raheem and Ramsbottom (2016) emphasized that, by enhancing local business, additional investment can be attracted to the local economy. McCrudden (2004) remarked that the inclusion of local criteria in public procurement can protect local contractors and workers from foreign companies, and CEEQUAL (2010) stated that the employment of local people or the use of local products and services can reduce the distances traveled to and from work and decrease the inconveniences over local communities. Finally, numerous authors referred to the important role of public procurement to boost social value, based on encouraging the contractors and subcontractors to commit to act in a socially responsible way (Petersen and Kadefors, 2016) from enhancing skills and knowledge among the professional community (GRI, 2011) to training and raising community awareness in relation to the sustainable development (Abdel-Raheem and Ramsbottom, 2016; ISI, 2015). 
The construction industry needs to change attitudes and practices toward workers and communities through the creation and maintenance of ethical values and responsibilities to society (Abdel-Raheem and Ramsbottom, 2016). Public procurement may be the tool to enforce respecting human rights in the construction industry (McCrudden, 2004). It may boost non-discriminatory practices by:hindering racial and sexual harassment and discrimination against the disabled (GRI, 2011);enhancing diversity and equal opportunities with respect to gender, age, disabilities, or cultural heritages (Popovic et al., 2018); working toward fair wages and fair income distributions;ensuring human rights implementation and integration represented by aspects such as child labor, forced labor, freedom of association, and collective bargaining (Popovic et al., 2018; UNEP, 2009); and minimizing corruption, which has been noted by several researchers as one of the main problems in the construction industry (Akenroye, 2013; Kenny, 2007).

Regarding public participation, communication between decision makers and communities should be established to avoid project failures ( $\mathrm{Li}$ et al., 2018) and to create value concerning public opinions (Abdel-Raheem and Ramsbottom, 2016). The project team should work closely with community stakeholders to identify and address issues and concerns (ISI, 2015). Thus, collecting, evaluating, and incorporating community input into each phase of the project life is required based on the development of community relations programs, which ensures its effective implementation (CEEQUAL, 2010; ISI, 2015; Sierra et al., 2015). Additionally, training is important to increase the skills, knowledge, and capacity of workers to enhance their growth and development (FHWA-INVEST, 2012; ISI, 2015). It builds the internal awareness and capacity necessary to prevent incidents of corruption (GRI, 2011) and improves labor aspects, sensitizing regarding each dimension of sustainable performance (Akenroye, 2013; Popovic et al., 2018).

Finally, adverse effects on neighbors can cause serious social costs; thus, they can be one of the most important aspects to deal with in a construction project (CEEQUAL, 2010). Possible disturbances on human communities need to be addressed (Ugwu et al., 2006). Lorries and transport of goods, materials, and staff associated with the construction project, work hours, etc., can cause a nuisance to the neighborhood (Abdel-Raheem and Ramsbottom, 2016; ISI, 2015). Additionally, construction projects can affect existing services. Consequently, actions may be required to allow communications with neighbors and to ensure the correct coordination with the involved stakeholders (CEEQUAL, 2010). Finally, construction work can affect access and mobility in existing infrastructures. The development of traffic management plans to minimize disruption is recommended (ISI, 2015).

\section{Research Method}

\subsection{Overall Approach}

In our study, the method selected to analyze the inclusion of social sustainability in construction public procurement was based on the analysis of tendering documents. In the scientific literature, methods that have been used to measure the state and progress of social sustainability in construction public procurement are mainly based on the use of questionnaires (Akenroye, 2013; Brammer and Walker, 2011; Sourani, 2008), interviews (Loosemore, 2016; Ruparathna and Hewage, 2015), and tender analyses (Akenroye, 2013; Hueskes et al., 2017; Ruparathna and Hewage, 2015). Each method shows several advantages but also some important limitations. A low response rate and self-selection bias associated 
with the use of questionnaires or interviews can influence the representativeness of the sample (Testa et al., 2016b). Interviews can offer good response rates, but the information gathered depends strongly on the judgment of the surveyor (Kippo-Edlund et al., 2005; Nissinen et al., 2009). Finally, tenders analysis may be strongly influenced by the interpretation by the researchers if the methods of analysis are not rigorous enough (Stanford et al., 2016). Several researchers have highlighted the adequacy of analyzing the content of public tenders to investigate the inclusion of sustainability criteria (Adham and Siwar, 2012; Nissinen et al., 2009).

To perform the analysis of tender documents, content analysis was the method developed in this research. Content analysis is a research method that is widely used for systematically and objectively identifying characteristics of large volumes of written material (Neuendorf, 2002). Content analysis is a method that may be used in an inductive or deductive way; it may be based on quantitative or qualitative descriptions (Bryman, 2012). An inductive method is used when there is insufficient knowledge about the phenomenon of study; hence, this approach is characterized as an open procedure in which categories can be defined or modified during the process of analysis (Essl and Mauerhofer, 2018). Deductive content analysis is performed when the analysis is structured to operate on the basis of previous knowledge, and the purpose of the study is theory testing (Bryman, 2012). On the other hand, the aim of a quantitative content analysis is to produce quantitative accounts of the analyzed material in terms of the established categories (Neuendorf, 2002), quantifying content in terms of predetermined categories in a systematic and replicable way (Sutterlüty et al., 2018). A qualitative content analysis is focused on the analysis of themes within the text through searching for certain ideas in it (Bryman, 2012), analyzing characteristics of language with attention to the content or contextual meaning of the text (Hsieh and Shannon, 2005), and developing a non-quantitative analysis (Neuendorf, 2002).

The content analysis of this research involves a quantitative content analysis that combines both inductive and deductive approaches. Thus, for its implementation, a characterization scheme composed of two levels was established. The first level was based on a group of pre-established categories centered on variables defined through an in-depth analysis of scientific literature, guides, and reports focused on social sustainability in the construction industry (Table 1). Following a deductive approach, these variables were used to undertake a first classification of the information contained in the tendering documents. The second level was formed by a group of sub-categories established as a result of an inductive process in each category. Consequently, this method allows describing and quantifying the information content in terms of predetermined categories, following a systematic approach that allows achieving valid inferences (Sierra et al., 2018b). Additionally, although content analysis is characterized by following a systematic approach, it is a subjective method, which must be based on a structured and replicable approach to maximize the objectivity of this research process (Rodrigues and Mendes, 2018).

In this paper, the research method follows the recommendations of Stanford et al. (2016). These authors proposed the following five steps, which are displayed in Figure 1:

1) identifying the variables and categories for the search and classification protocol;

2) collecting the tender documents;

3) analyzing the documents according to the protocol;

4) establishing inter-rater reliability; and 
5) using descriptive statistics to characterize the results and using statistical analysis to determine the significance of these.

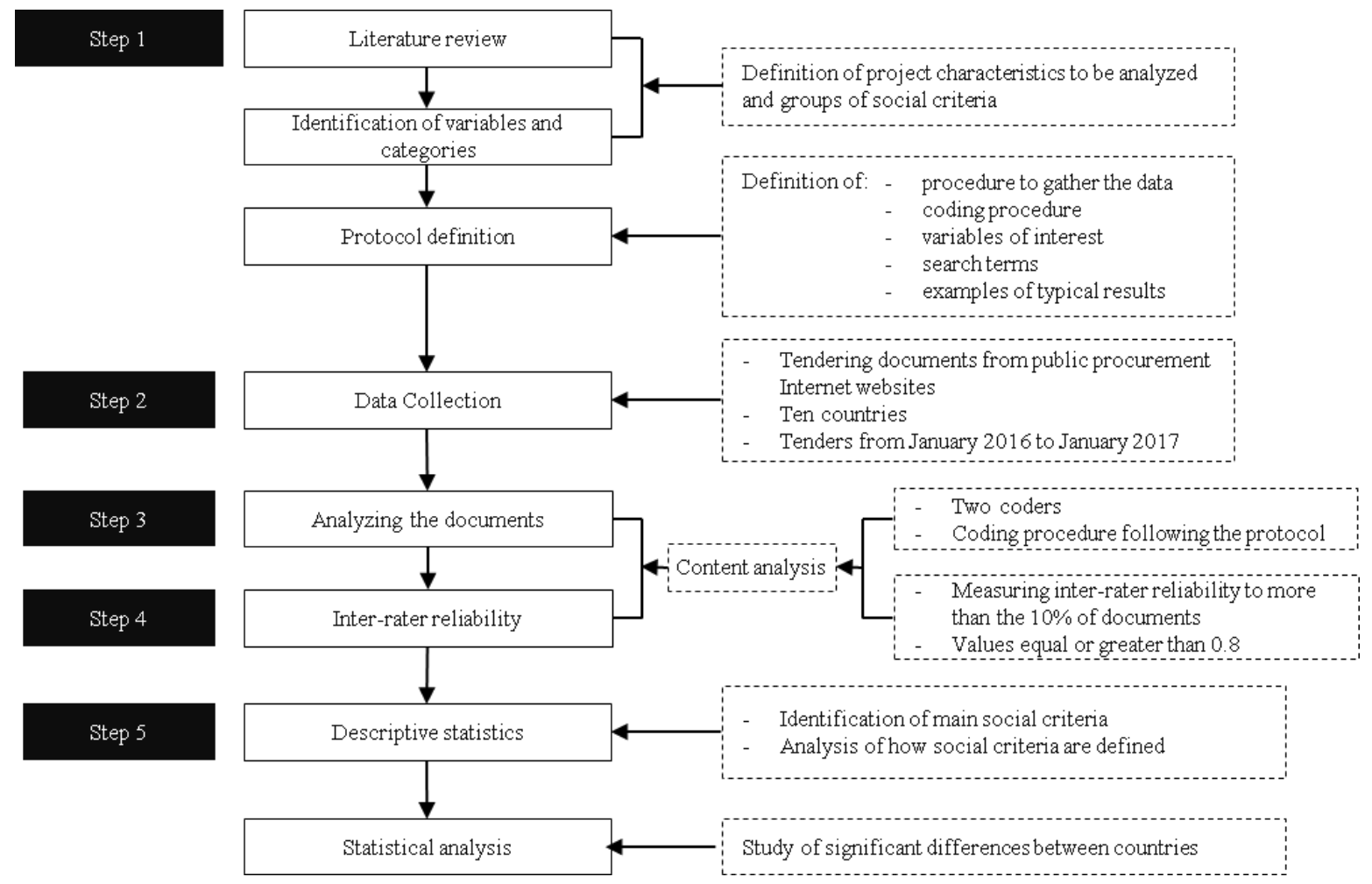

Figure 1. Research process.

\subsection{Identification of Variables and Categories}

In Step 1, through a literature review, the research team identified the main variables and categories to undertake the first level of content analysis. First, three variables were defined to characterize the tendering projects in terms of the following: infrastructure type, discriminating between buildings and civil engineering projects (Gransberg and Barton, 2007; Xia et al., 2013);contract size, represented by the initial budget of the project ( $€$ ) (Lines and Miao, 2016; Stanford et al., 2016; Xia et al., 2013); and duration of the contract (year) (Stanford et al., 2016).Second, eight categories were referred to the eight groups of social criteria defined at the conclusion of the literature review. Thus, these eight categories were (Table 1) cultural heritage, employment, health and safety, local, professional ethics, public participation, training, and users' impact.

Based on these variables and categories, a protocol was developed to establish the procedure to gather information, enabling later replication of the research process. The protocol established the coding procedure and variables of interest and recommended the search terms and examples of expected typical results, according to the recommendations of Neuendorf (2002) and Stanford et al. (2016) (see Supplementary Material). 
Table 1 . Study variables

\begin{tabular}{cl}
\hline Categories & \multicolumn{1}{c}{ Literature Source } \\
\hline Cultural heritage & ISI, 2015; Kylili et al., 2016; Shen et al., 2005; Ugwu et al., 2006; Ugwu and Haupt, 2007 \\
\hline Employment & $\begin{array}{l}\text { Azapagic and Perdan, 2000; Balubaid et al., 2015; FIDIC, 1999; Global Reporting Initiative, 2011; Lim, 2009; } \\
\text { Shen et al., 2005; Sierra et al., 2017 }\end{array}$ \\
\hline Health and safety & Amiril et al., 2014; FHWA-INVEST, 2012; Jeon and Amekudzi, 2005; Kylili et al., 2016; Tam et al., 2004 \\
\hline Local & $\begin{array}{l}\text { Dobrovolskiien and Tamošiluniene, 2016; FIDIC, 1999; Global Reporting Initiative, 2011; Jeon and Amekudzi, } \\
\text { 2005; Lim, 2009; Shen et al., 2011; Ugwu et al., 2006; Ugwu and Haupt, 2007 }\end{array}$ \\
\hline Professional ethics & FIDIC, 1999; Global Reporting Initiative, 2011; Jeon and Amekudzi, 2005; Sierra et al., 2015; Ugwu et al., 2006; \\
& Ugwu and Haupt, 2007; Veeravigrom et al., 2015 \\
\hline Public participation & Bovaird, 2006; Dobrovolskiien and Tamošiluniene, 2016; Jeon and Amekudzi, 2005; Kylili et al., 2016; Reverte, \\
& 2015; Sierra et al., 2017; Ugwu et al., 2006; Ugwu and Haupt, 2007) \\
\hline Training & Azapagic and Perdan, 2000; Dobrovolskiien and Tamošiluniene, 2016; Global Reporting Initiative, 2011; \\
& Muench et al., 2012; Sierra et al., 2015; Tam et al., 2004 \\
\hline Users’ impact & FHWA-INVEST, 2012; Jeon and Amekudzi, 2005; Krajangsri and Pongpeng, 2017; Ugwu et al., 2006; Ugwu \\
& and Haupt, 2007 \\
\hline
\end{tabular}

\subsection{Data Collection}

Once the protocol was defined and the scope of this research was established, Step 2 (associated with collecting tender documents) was implemented. To collect tendering documents, public procurement Internet websites in each country were searched for construction products and services to capture the most recent trends. Tender documents were gathered from those countries whose tender documents were available free online and were published in English or Spanish. The search was conducted from January 2016 to January 2017.

To select the appropriate documents, the classification system of each country for public procurement was identified since each country has a classification system for public procurement that aims to standardize the references used to contract authorities and entities and to describe the subject of procurement contracts (Europe: Common Procurement Vocabulary, Australia and New Zealand: The United Nations Standard Products and Services Code, Chile: The classification of United Nations (ONU), among others). A total of 534 tender documents from 13 countries were obtained as initial candidates from the database. However, to carry out a comprehensive and homogeneous study of each project, only those tender documents that included tender characteristics, technical specifications of the project, and contract performance clauses were selected. For this reason, countries such as New Zealand, South Africa, and Mexico were excluded. Finally, 451 tender documents were selected from the following 10 countries: Argentina, Australia, Canada, Chile, Colombia, Panama, Peru, Spain, the United Kingdom, and the United States.

\subsection{Content Analysis}

After gathering the tendering documents, the documents were analyzed following the protocol (Step 3), and inter-rater reliability was established (Step 4). Following the recommendations of Stanford et al. (2016), two coders examined one tendering document randomly selected from each country to refine the coding process and ensure consistency. Then, 50 tendering documents, more than $10 \%$ of the total of documents gathered (Cohen, 1960), were randomly selected for independent coding to measure inter-rater reliability. This ensures that the units of analysis were independent, the established variables were independent, and the judges of the coders operated independently (Cohen, 1960). 
For the continuous variable (contract size), the authors calculated the percentage of agreement between raters $\left(P A_{o}\right)$. This is a measure that is widely used and easily understood for determining inter-rater agreement (Neuendorf, 2002; Stanford et al., 2016). The observed proportion of agreement is simply calculated as the number of agreements between raters divided by the total number of units coded by both raters. For the discrete variables (the rest of the analyzed variables), Cohen's kappa (Cohen, 1960) was selected to calculate the inter-rater reliability. This indicator of agreement has been widely used internationally due to having the additional benefit of accounting for chance agreements among raters selected between pre-defined categories (Neuendorf, 2002). Cohen’s kappa is calculated as follows:

$$
\kappa=\left(P A_{o}-P A_{g}\right) /\left(1-P A_{g}\right)
$$

where $P A_{o}$ is the proportion of agreement observed, and $P A_{g}$ is the proportion of agreement expected by chance (for additional details on the calculation of $P A_{g}$ see Cohen, 1960). Both measures, $P A_{o}$ (for continuous) and $\kappa$ (for discrete), range from 0.0 to 1.0, with 1.0 indicating perfect agreement. Values equal to or greater than 0.80 and above are often considered satisfactory (Neuendorf, 2002; Stanford et al., 2016). In this research, inter-rater reliability proved satisfactory by achieving values over or equal to 0.8 for every variable.

\subsection{Statistical Analysis}

When the coding process was completed, Step 5 was carried out. An inductive procedure was developed to cluster the gathered information for each category in sub-categories. To analyze how social criteria are defined, the following two terms were differentiated based on Winter and Lasch (2016): indicator and metric. Sustainability indicators are generally used to evaluate and motivate progress toward sustainability objectives (e.g., to promote employment of non-qualified personnel from the influenced region during the development of this project); however, the metrics of sustainability are those indicators that submit quantitative associated measurement (e.g., to employ at least $x \%$ of non-qualified personnel from the influenced region during the development of the project). Once the data were prepared following these premises, the descriptive statistics and statistical analysis were developed to reach the research goals identified in this study.

Descriptive statistics were used to determine the main social criteria in accordance with different selected countries. This analysis was developed under the assumption that each group of criteria was identified at least once in each tendering document. The objective was to avoid the possible variability associated with the modus operandi of each public agency, trying to show a normalized comparison based on frequencies of appearance.

To conduct a comparative analysis between countries, considering that the data sample is categorical, a correspondence analysis was developed to analyze similar trends between countries. According to Hair et al. (2014), this technique is the most appropriate as an exploratory method to identify unrecognized dimensions that affect behavior, as an alternative to obtaining comparative results when the specific bases of comparison are not known or are not defined. Correspondence analysis is a multivariable statistical technique. It provides a detailed analysis of the relationships between categorical data and a graphical illustration of the data in two-dimensional space (Hair et al., 2014; Yildirim et al., 2017). This technique has been used by researchers to demonstrate similarities and differences in judgment models (Jelodar et 
al., 2017), to analyze the interaction of multi-criteria decision-making methods with the life-cycle phases of infrastructures (Penadés-Plà et al., 2016) or construction industry aspects (Jato-Espino et al., 2014), and to study the relation between knowledge and public perception in an analyzed sample (De Gisi et al., 2017).

A simple correspondence analysis (SCA) enables researchers to visualize the correlations between variables and the possible existence of groups into the graph based on the distances between variables (Jelodar et al., 2017). This technique is based on the chi-square statistics to standardize the frequency value and to constitute the basis of associations (Hair et al., 2014). Inertia is directly related to chi-square statistics and demonstrates the relationship between the variable categories depending on the chi-square values of each section or row (Jelodar et al., 2017; Sourial et al., 2010). Departing from the inertia value, the correspondence analysis creates orthogonal dimensions to represent the variables, considering the strength of their associations (Hair et al., 2014; Yildirim et al., 2017). Each dimension has an eigenvalue. Eigenvalues demonstrate the relative importance of the dimensions and the extent to which each dimension contributes to the total inertia (Hair et al., 2014; Sourial et al., 2010). Thus, first, the data were structured in the form of a contingency table composed of rows (groups of social criteria) and columns (countries). Second, a SCA was developed using IBM SPSS Statistics (23.0) to assess the correlation between variables. Finally, a statistical analysis was developed to assess the possible significant differences between countries in terms of social criteria.

\section{Results}

\subsection{Sample Characterization}

The dataset includes 451 tendering documents representing a wide variety of government agencies from 10 countries. Moreover, $67 \%$ of the tendering documents represent a total contracting capacity above 6 billion euros, while the other 33\% correspond to projects in which the budget is not previously specified at the award phase. This scenario is notably common in countries such as Australia, Canada, and, to a lesser extent, the United Kingdom. In addition, 26\% of analyzed tenders correspond with building projects and 74\% with civil engineering projects. Figure 3 illustrates that these proportions are similar for each category of contract size. The following four contract sizes were defined according to the gathered data: projects with a budget less than one million euros, projects with a budget between one and 10 million euros, projects with a budget greater than 10 million euros, and projects with an unspecified budget in the tendering phase. Finally, regarding the contract duration, four groups were defined: 316 tendering documents had duration shorter than 2 years, 59 were between 2 and 5 years, 67 were between 5 and 10 years, and nine were longer than 10 years. Table 2 and Figure 2 show detailed information about the collected sample.

Table 2. Summary of the data sample.

\begin{tabular}{cccccccc}
\hline \multirow{2}{*}{ Country } & & \multicolumn{2}{c}{ Infrastructure Type } & \multicolumn{4}{c}{ Contract Size } \\
\cline { 3 - 7 } & Tenders & Building & $\begin{array}{c}\text { Civil } \\
\text { Engineering } \\
\text { Projects }\end{array}$ & $<1,000,000 €$ & $\begin{array}{c}1,000,000 €- \\
10,000,000 €\end{array}$ & $\begin{array}{c}> \\
10,000,000 €\end{array}$ & Unspecified \\
\hline Argentina & 29 & $13.8 \%$ & $86.2 \%$ & $27.6 \%$ & $44.8 \%$ & $10.3 \%$ & $17.2 \%$ \\
\hline
\end{tabular}




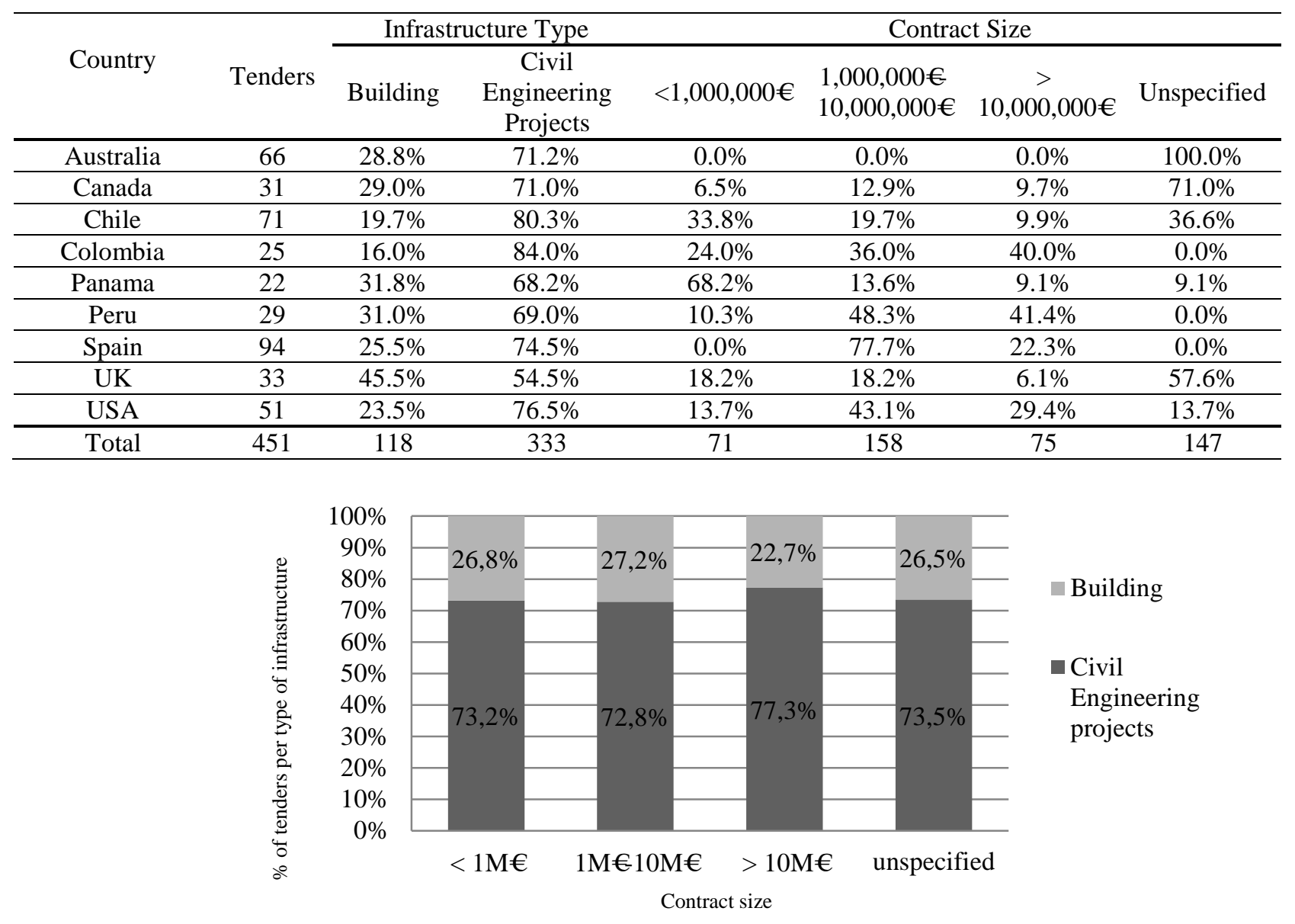

Figure 2. Distribution of percentage of tenders per contract size.

\subsection{Descriptive Analysis}

The information gathered in tendering documents for each one of the categories was grouped in subcategories using the affinity diagram technique (Carnevalli and Miguel, 2008). Subsequently, the terms metrics and indicators were used to classify the information gathered for each group of social criteria. Table 3 shows the 23 sub-categories established through the inductive process. The most considered subcategories are workplace health and safety management plans, employment of vulnerable groups, avoiding or minimizing mobility disruption, and technical and sustainability training of workers. Except for the sub-category of employment of vulnerable groups, the rest are characterized by an absence of metrics to be assessed. Contrarily, sub-categories related to professional expertise in cultural heritage and occupation health and safety certifications were the least included despite their easy quantification. Moreover, within the 451 analyzed tendering documents, 2,724 social indicators were included, and only $19 \%$ of them had associated metrics. This indicates the lack of objective methods to assess the social sustainability in public-work procurement.

Regarding the use of social indicators depending on the contract size and contract duration, the distribution of the total of social indicators considering the different contract sizes was (Figure 3): $42 \%$ for projects with an unspecified budget, 18\% for projects greater than $10 \mathrm{M} €, 30 \%$ for projects between 
$1 \mathrm{M} €$ and $10 \mathrm{M} €$, and $10 \%$ for projects smaller than $1 \mathrm{M} €$. Additionally, the distribution of indicators with metrics was $46 \%$ for projects between $1 \mathrm{M} €$ and $10 \mathrm{M} €$. On the other hand, the average number of social indicators included in the tendering documents was 3.9 for projects with a budget smaller than $1 \mathrm{M} €, 5.2$ for projects between $1 \mathrm{M} €$ and $10 \mathrm{M} €, 6.3$ for projects greater than $10 \mathrm{M} €$, and 7.8 for projects with an unspecified budget. Thus, the inclusion of social indicators strongly increases as the contract size rises. However, concerning contract duration, the average social indicators per tender was 5.7 for projects shorter than 2 years, 6.7 for projects between 2 and 5 years, 6.8 for projects between 5 and 10 years, and 7 for projects longer than 10 years. Hence, although both contract size and contract duration present a similar trend, regarding contract duration, great differences were only found between projects shorter than 2 years and projects above 2 years.

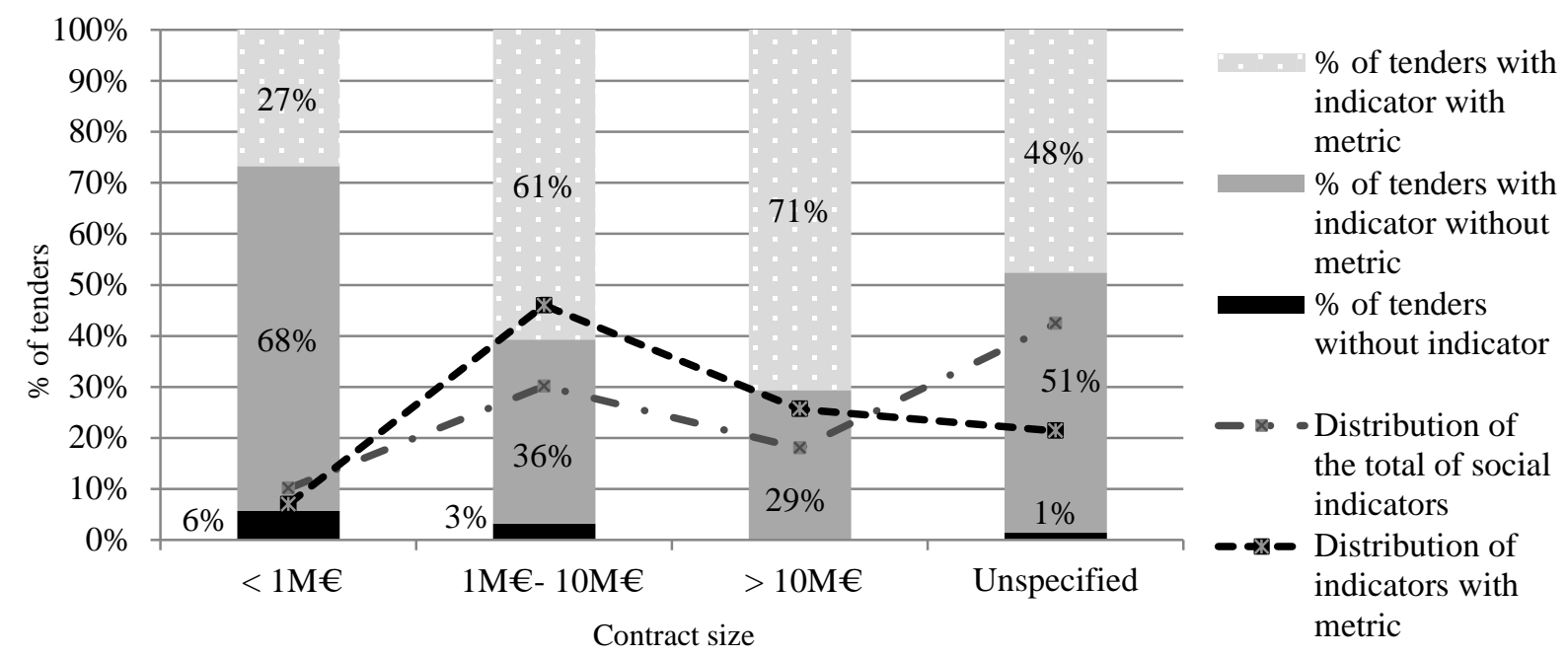

Figure 3. Percentage of tenders that contain social indicators and percentage of distribution of the gathered social indicators.

Additionally, the inclusion of indicators with metrics was analyzed. Figure 3 shows that only $7 \%$ of indicators with metrics were for projects with a budget less than $€ 1 \mathrm{M}$, whereas the remaining percentage was distributed similarly in the other two groups of projects. The average number of social metrics included in the tendering documents was 0.5 for projects with a budget smaller than $1 \mathrm{M} €, 1.5$ for projects between $1 \mathrm{M} €$ and $10 \mathrm{M} €, 1.76$ for projects greater than $10 \mathrm{M} €$, and 0.75 for projects with an unspecified budget. Consequently, a slight increase in the inclusion of metrics is accompanied with the growth of contract sizes. On the other hand, results associated with the inclusion of metrics depending on the contract duration do not show this trend. The average number of social metrics was 1 for projects shorter than 2 years, 1.9 for projects with duration between 2 and 5 years, 1.3 for projects between 5 and 10 years, and 0.8 for projects with duration longer than 10 years.

Figure 4 represents the percentage of consideration of each category in the analyzed sample. The number of times that the category health and safety is considered is notably higher in comparison with the rest of the categories. This is followed by employment, users' impact, professional ethics, and training. In contrast, the percentage of tenders that consider local, cultural heritage, and public participation criteria is less than 30\%. It is important to highlight the low percentage of instances associated with public participation criteria, having been considered only in $21 \%$ of the tendering documents. This result may be 
because the legislation of most of the countries mandates citizen participation in different phases of the tendering procedure, making it unnecessary to include this type of criterion in the documents of the tendering criteria since it is an action that is inherent to the procedure. This fact makes the analysis of this category unrepresentative; consequently, the authors have considered eliminating it in the next stage of the analysis.

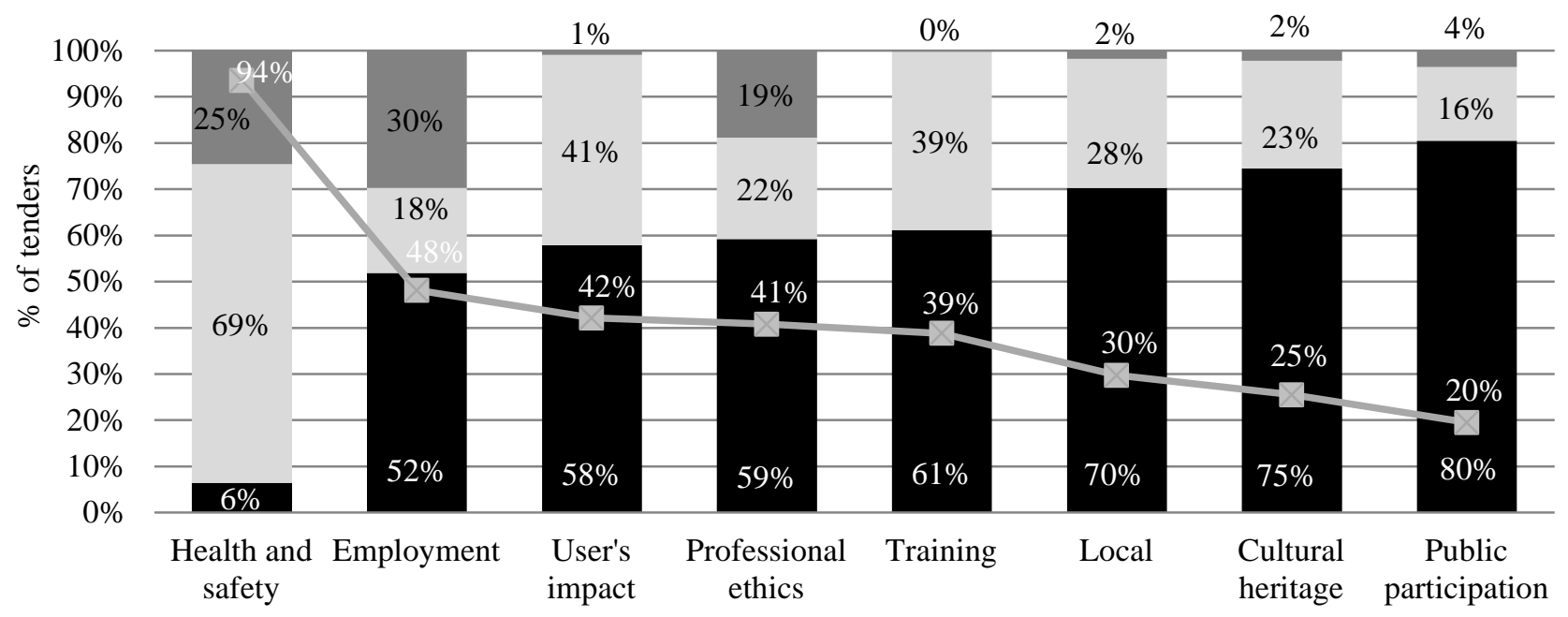

$\%$ with indicator with metric

Social criteria

$\%$ without indicator

$\%$ with indicator without metric

$-\varangle-\%$ of tender in which the social criteron is included

Figure 4. Percentage of consideration of each group of social criteria. 
Table 3: Social criteria and categories of social indicators.

\begin{tabular}{|c|c|c|c|c|c|c|}
\hline $\begin{array}{l}\text { Categories } \\
\text { of Social } \\
\text { Criteria }\end{array}$ & Sub-category of Social Indicators & $\begin{array}{c}\text { Sum of Category } \\
\text { Appearance in Tender A }\end{array}$ & $\begin{array}{c}\text { Percentage of A } \\
\text { Considered with Metrics }\end{array}$ & $\begin{array}{c}\text { Sum of Tenders in } \\
\text { Category B }\end{array}$ & $\begin{array}{c}\text { Percentage of } \\
\text { Tender in Category }(*)\end{array}$ & $\begin{array}{l}\text { Percentage of B Including } \\
\text { Indicators with Metrics }\end{array}$ \\
\hline \multirow{3}{*}{$\begin{array}{l}\text { Cultural } \\
\text { heritage }\end{array}$} & Preservation of historic and cultural resources & 117 & - & 109 & $24 \%$ & - \\
\hline & Professional expertise in cultural heritage & 11 & $100 \%$ & 10 & $2 \%$ & $100 \%$ \\
\hline & Total & 128 & $9 \%$ & 111 & $25 \%$ & $9 \%$ \\
\hline \multirow{5}{*}{ Employment } & Employment created or retained & 107 & $4 \%$ & 91 & $20 \%$ & $4 \%$ \\
\hline & Employment of vulnerable groups & 272 & $74 \%$ & 176 & $39 \%$ & $72 \%$ \\
\hline & Job stability & 65 & $97 \%$ & 60 & $13 \%$ & $97 \%$ \\
\hline & Industry participation plan & 54 & - & 51 & $11 \%$ & - \\
\hline & Total & 498 & $54 \%$ & 217 & $48 \%$ & $62 \%$ \\
\hline \multirow{5}{*}{$\begin{array}{l}\text { Health and } \\
\text { safety }\end{array}$} & Workplace health and safety management plan & 569 & $1 \%$ & 414 & $92 \%$ & - \\
\hline & Public safety & 164 & $3 \%$ & 147 & $33 \%$ & $3 \%$ \\
\hline & Occupation health and safety certifications & 36 & $91 \%$ & 34 & $8 \%$ & $91 \%$ \\
\hline & Professional expertise in health and safety & 83 & $99 \%$ & 76 & $17 \%$ & $99 \%$ \\
\hline & Total & 852 & $14 \%$ & 422 & $94 \%$ & $26 \%$ \\
\hline \multirow{4}{*}{ Local } & Local preference & 47 & - & 44 & $10 \%$ & - \\
\hline & Local participation & 138 & $7 \%$ & 101 & $22 \%$ & $8 \%$ \\
\hline & Social value & 60 & - & 44 & $10 \%$ & - \\
\hline & Total & 245 & $4 \%$ & 134 & $30 \%$ & $6 \%$ \\
\hline \multirow{5}{*}{$\begin{array}{l}\text { Professional } \\
\text { ethics }\end{array}$} & Non-discriminatory hiring practices & 38 & $3 \%$ & 38 & $8 \%$ & $3 \%$ \\
\hline & Commitment to anti-corruption & 52 & - & 52 & $12 \%$ & - \\
\hline & Gender equality & 131 & $66 \%$ & 128 & $28 \%$ & $66 \%$ \\
\hline & Fair wages & 65 & - & 64 & $14 \%$ & - \\
\hline & Total & 286 & $31 \%$ & 184 & $41 \%$ & $46 \%$ \\
\hline \multirow{2}{*}{$\begin{array}{c}\text { Public } \\
\text { participation }\end{array}$} & Public participation & 177 & $9 \%$ & 97 & $22 \%$ & $18 \%$ \\
\hline & Total & 177 & $9 \%$ & 97 & $22 \%$ & $18 \%$ \\
\hline \multirow{2}{*}{ Training } & Technical and sustainability training of workers & 212 & - & 175 & $39 \%$ & $1 \%$ \\
\hline & Total & 212 & - & 175 & $39 \%$ & $1 \%$ \\
\hline \multirow{4}{*}{$\begin{array}{l}\text { Users' } \\
\text { impact }\end{array}$} & $\begin{array}{c}\text { Avoiding or minimizing the harm done to the } \\
\text { neighborhood }\end{array}$ & 89 & - & 80 & $18 \%$ & - \\
\hline & $\begin{array}{l}\text { Avoiding or minimizing the harm done to the } \\
\text { existing services }\end{array}$ & 14 & - & 14 & $3 \%$ & - \\
\hline & Avoiding or minimizing mobility disruption & 223 & $2 \%$ & 159 & $35 \%$ & $3 \%$ \\
\hline & Total & 326 & $1 \%$ & 190 & $42 \%$ & $2 \%$ \\
\hline
\end{tabular}

$\left.{ }^{*}\right)$ With respect to the 451 analyzed tenders. 
To show a representative picture of the variability of the consideration of social criteria at the international level, Figure 5 shows the distribution of the percentage of inclusion of each category in each country. A wide variability (from $0 \%$ to $80 \%$ ) generally exists with respect to their inclusion, except the health and safety category, which were considered in over $70 \%$ of the documents in every country. Alternatively, cultural heritage is the least considered category since there is no country that includes this factor in more than $50 \%$ of the tender documents.

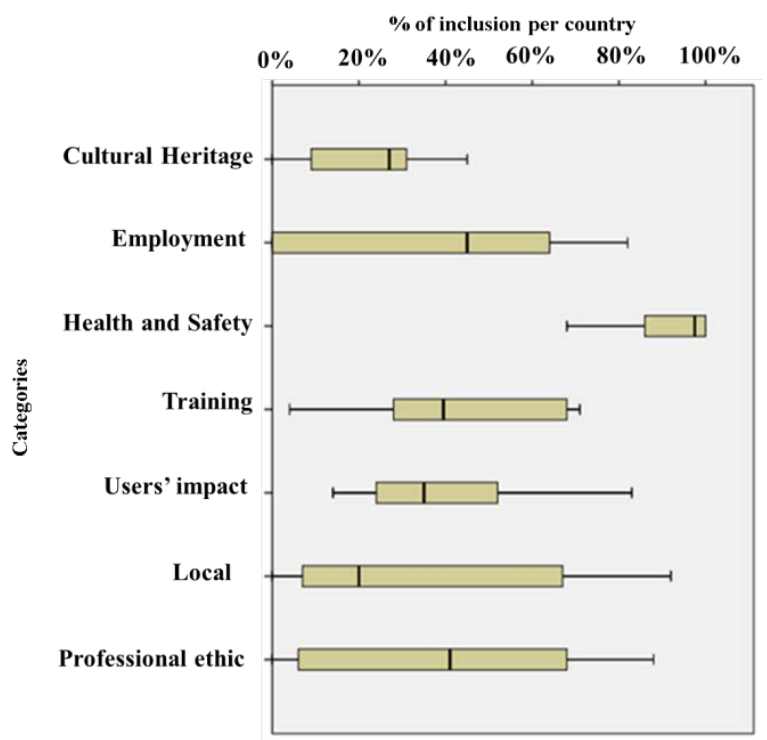

Figure 5. Distribution of percentage of consideration of each group of social criteria in each country.

These distributions can be notably varied, depending on the contract size of the project. Table 4 shows the median of the percentage of consideration for each social criterion in each country, considering the different groups of contract size. Although the median of the health and safety criterion remains fixed at approximately $100 \%$, for different groups of contracts, generally, the rest of the criteria show important increases as the budget size is raised. Accordingly, the median of employment increased $40 \%$ from projects smaller than $1 \mathrm{M} €$ to projects over $1 \mathrm{M} €$. Cultural heritage changed 27\%. Users' impact changed $25 \%$, while professional ethics increased 32\%, and training increased 35\%. However, the median of local criteria tended to decrease as the contract size increased. That value varied from $0 \%$ for projects over the $10 \mathrm{M} €$ to a range of between $20 \%$ and $30 \%$ for the remaining cases.

Table 4. Median of percentage of consideration of each group of social criteria in each country per contract size.

\begin{tabular}{llllllll}
\hline $\begin{array}{l}\text { Median by Contract } \\
\text { Size }\end{array}$ & $\begin{array}{l}\text { Cultural } \\
\text { Heritage }\end{array}$ & Employment & $\begin{array}{l}\text { Health and } \\
\text { Safety }\end{array}$ & Training & $\begin{array}{l}\text { Users' } \\
\text { Impact }\end{array}$ & $\begin{array}{l}\text { Local } \\
\text { Professional } \\
\text { Ethics }\end{array}$ \\
\hline$<1 \mathrm{M} €$ & $0 \%$ & $9 \%$ & $100 \%$ & $16 \%$ & $20 \%$ & $33 \%$ & $25 \%$ \\
\hline $1 \mathrm{M}-10 \mathrm{M} €$ & $20 \%$ & $50 \%$ & $100 \%$ & $29 \%$ & $29 \%$ & $21 \%$ & $50 \%$ \\
\hline$>10 \mathrm{M} €$ & $27 \%$ & $56 \%$ & $100 \%$ & $50 \%$ & $45 \%$ & $0 \%$ & $57 \%$ \\
\hline unspecified & $27 \%$ & $37 \%$ & $100 \%$ & $55 \%$ & $50 \%$ & $32 \%$ & $14 \%$ \\
\hline
\end{tabular}


Finally, an analysis was performed focused on countries to characterize the inclusion of social indicators and metrics in their tendering documents (Table 5). In general, the average of categories per tender is 3.18. The USA, the UK, and Australia overcame this value, covering an average of four categories per tender. These countries are followed by Colombia (3.36). According to the average of categories included in tendering documents per country, the USA, the UK, and Australia include social categories the most. However, Spain (2.65), the USA (1.57), and Colombia (1.32) have greater inclusion of metrics per tender. Additionally, the low number of metrics included per tender at the international level is illustrated in Table 5.

Table 5. Inclusion of indicators per country.

\begin{tabular}{|c|c|c|c|c|}
\hline Country & Indicators per tender & $\begin{array}{c}\text { Indicators with metric } \\
\text { per tender }\end{array}$ & $\begin{array}{c}\text { Average of categories } \\
\text { per tender }\end{array}$ & Standard deviation \\
\hline Argentina & 3.97 & 0.14 & 2.48 & 1.35 \\
\hline Australia & 10.42 & 0.89 & 4.18 & 1.29 \\
\hline Canada & 4.87 & 0.26 & 2.87 & 1.69 \\
\hline Chile & 5.86 & 0.62 & 2.72 & 1.88 \\
\hline Colombia & 7.24 & 1.32 & 3.36 & 1.29 \\
\hline Panama & 3.00 & 0.05 & 2.09 & 1.23 \\
\hline Peru & 2.07 & 0.55 & 1.38 & 0.86 \\
\hline Spain & 4.72 & 2.65 & 2.62 & 1.34 \\
\hline UK & 7.21 & 0.64 & 4.24 & 1.58 \\
\hline USA & 7.16 & 1.57 & 4.84 & 1.55 \\
\hline Total & 6.04 & 1.14 & 3.18 & 1.75 \\
\hline
\end{tabular}

\subsection{Correspondence Analysis}

To carry out a comparative analysis between countries, the authors first globally analyzed the data sample. An SCA was developed. The chi-square $\left(\chi^{2}\right)$ test of independence was undertaken to determine whether there was a relationship between the social criteria and countries. The null hypothesis $\left(\mathrm{H}_{0}\right)$ was that an independent relationship between the variables exists, being satisfied when $p>0.05$. The results showed that $\chi^{2}$ was 452.039 and $p=0.000$. Therefore, $\mathrm{H}_{0}$ was rejected, and it was determined that there is a relation between the social criteria and the studied countries.

Additionally, the SCA showed that four dimensions were needed to explain $88.5 \%$ of the total inertia (0.375). Consequently, to obtain more detailed information, four correspondence analyses were developed to assess the groups of the project individually, based on the contract size. The distribution of the data in two-dimensional space and the visualization of the correlations between variables for each group of projects were carried out. The chi-square test of independence was conducted within each group to determine whether there was a relationship between countries and social criteria. The results showed that, in each group of projects, there was a dependent relation between the countries and social criteria. However, projects smaller than $1 \mathrm{M} €$ presented different behavior patterns compared to the remaining sample, since the distribution of the data was different, and more than two dimensions were needed to represent the data of this group of projects. Hence, the authors decided to select the group formed by projects with a budget over $1 \mathrm{M} €$ and projects with an unspecified budget (87\% of the sample) to carry out the comparative analysis between countries. 
Regarding the group formed by projects with a budget over $1 \mathrm{M€}$ and projects with an unspecified budget, an SCA was developed. The results showed a dependent relation between social criteria and countries $\left(\chi^{2}: 196.674\right.$ and $\left.p: 0.000\right)$. Two dimensions were needed to explain $80 \%$ of the total inertia (0.187) (Tables 6 and 7). The first dimension explained $61 \%$ of the total inertia, and the second dimension explained $19 \%$ of the total inertia. Every country and every group of social criteria was well explained by these dimensions, having achieved values over $75 \%$. Only cultural heritage and local criteria presented a minimum value of representation ( $22 \%$ and $35 \%$, respectively); thus, the authors decided to eliminate them from this representation.

Table 6. Overview row points: Correspondence analysis.

\begin{tabular}{|c|c|c|c|c|c|c|c|c|c|}
\hline \multirow{3}{*}{$\begin{array}{l}\text { Categories of } \\
\text { social criteria }\end{array}$} & \multirow{3}{*}{ Mass } & \multicolumn{2}{|c|}{ Score in dimension } & \multirow{3}{*}{ Inertia } & \multicolumn{5}{|c|}{ Contribution } \\
\hline & & \multirow[t]{2}{*}{1} & \multirow[t]{2}{*}{2} & & \multicolumn{2}{|c|}{$\begin{array}{c}\text { Of point to inertia of } \\
\text { dimension }\end{array}$} & \multicolumn{3}{|c|}{ Of dimension to inertia of point } \\
\hline & & & & & 1 & 2 & 1 & 2 & Total \\
\hline Employment & 0.192 & -0.560 & 0.234 & 0.034 & 0.191 & 0.049 & 0.562 & 0.197 & 0.759 \\
\hline $\begin{array}{l}\text { Health and } \\
\text { safety }\end{array}$ & 0.343 & 0.134 & -0.631 & 0.031 & 0.020 & 0.637 & 0.063 & 0.937 & 1.000 \\
\hline Training & 0.150 & 0.780 & 0.451 & 0.044 & 0.290 & 0.143 & 0.661 & 0.150 & 0.810 \\
\hline Users’ impact & 0.161 & 0.494 & 0.417 & 0.028 & 0.124 & 0.131 & 0.564 & 0.216 & 0.780 \\
\hline $\begin{array}{c}\text { Professional } \\
\text { ethics }\end{array}$ & 0.154 & -0.877 & 0.236 & 0.050 & 0.375 & 0.040 & 0.744 & 0.036 & 0.780 \\
\hline Active total & 1.000 & & & 0.187 & 1.000 & 1.000 & & & \\
\hline
\end{tabular}

Table 7. Overview column points: Correspondence analysis

\begin{tabular}{|c|c|c|c|c|c|c|c|c|c|}
\hline \multirow{3}{*}{ Countries } & \multirow{3}{*}{ Mass } & \multicolumn{2}{|c|}{ Score in dimension } & \multirow{3}{*}{ Inertia } & \multicolumn{5}{|c|}{ Contribution } \\
\hline & & \multirow[t]{2}{*}{1} & \multirow[t]{2}{*}{2} & & \multicolumn{2}{|c|}{$\begin{array}{c}\text { Of point to inertia of } \\
\text { dimension }\end{array}$} & \multicolumn{3}{|c|}{ Of dimension to inertia of point } \\
\hline & & & & & 1 & 2 & 1 & 2 & Total \\
\hline Spain & 0.215 & -0.731 & -0.360 & 00.047 & 0.363 & 0.130 & 0.768 & 0.126 & 0.894 \\
\hline Australia & 0.202 & 0.669 & 0.296 & 0.043 & 0.285 & 0.083 & 0.664 & 0.088 & 0.753 \\
\hline Panama & 0.013 & 1.383 & -0.431 & 0.013 & 0.081 & 0.012 & 0.615 & 0.165 & 0.780 \\
\hline Colombia & 0.047 & -0.504 & 0.351 & 0.006 & 0.038 & 0.027 & 0.666 & 0.220 & 0.886 \\
\hline Chile & 0.132 & -0.175 & -0.014 & 0.003 & 0.013 & 0.000 & 0.580 & 0.178 & 0.758 \\
\hline USA & 0.168 & -0.218 & 0.392 & 0.015 & 0.025 & 0.121 & 0.395 & 0.490 & 0.885 \\
\hline Canada & 0.062 & 0.616 & 0.015 & 0.009 & 0.074 & 0.000 & 0.854 & 0.000 & 0.855 \\
\hline UK & 0.092 & -0.019 & 0.310 & 0.009 & 0.000 & 0.041 & 0.301 & 0.450 & 0.751 \\
\hline Argentina & 0.036 & 0.693 & -0.809 & 0.015 & 0.055 & 0.110 & 0.383 & 0.369 & 0.752 \\
\hline Peru & 0.032 & 0.800 & -1.776 & 0.029 & 0.066 & 0.476 & 0.228 & 0.764 & 0.992 \\
\hline Active total & 1.000 & & & 0.187 & 1.000 & 1.000 & & & \\
\hline
\end{tabular}

Figure 6 shows the correlations between variables. According to the axis "A1" defined by the authors, two groups of countries can be clearly differentiated: the group formed by Anglo-Saxon countries (ASCs) and the group formed by Spanish-speaking countries (SSCs). The main differences between these groups are associated with the consideration of the users' impact and the training criteria. Although both groups notably consider health and safety criteria, ASCs consider users' impact and training criteria in more than the $75 \%$ of their tenders; however, in SSCs, these criteria are under 38\%. Consequently, ASCs were displaced in the plot compared to SSCs along the axis "A2." Moreover, SSCs consider each group of social criteria at a lower percentage than ASCs. Thus, SSCs are further from the social criteria in the plot. 


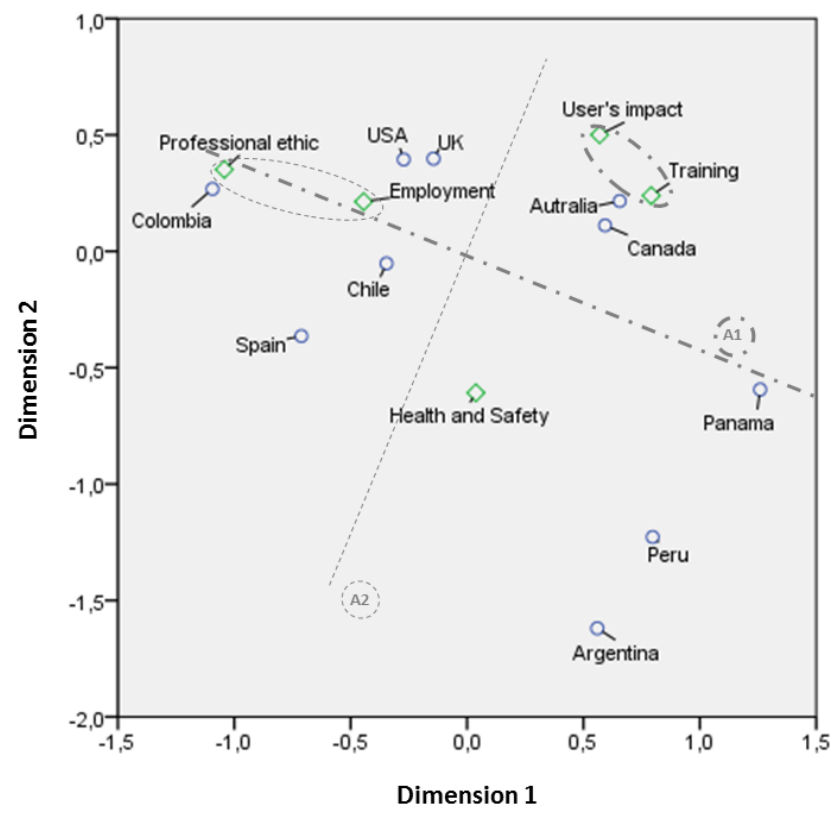

Country

$\checkmark$ Social criteria

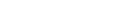

Figure 6. Correlation diagram between countries and social categories.

Additionally, within each group of countries, important differences can be highlighted, considering axis "A2." The consideration for professional ethics and employment criteria from every country causes the distribution of these along axis "A1.” Accordingly, within the SSCs, Colombia, Spain, and Chile are the countries that most consider these criteria. Similar patterns are presented by the USA and the UK with respect to the rest of the ASCs.

These results were verified through a chi-square $\left(\chi^{2}\right)$ contingency table analysis (Tables 8 and 9), which is one of the most commonly used statistical analyses for categorical data analysis (Xia et al., 2012). Table 8 shows the results of the comparison between both groups of countries, and Table 9 shows the main differences within each group of countries. The chi-square contingency table analysis determines the extent to which a statistical relationship exists between two variables (Field, 2013; McClave et al., 2010). The null hypothesis was that a dependent relationship between the variables does not exist, being satisfied when $p>0.05$. In this case, the groups of countries present similar patterns for the social criteria. In contrast, in the case in which the null hypothesis is rejected and the results show that the relationship between the variables is dependent, the Phi correlation coefficient would be selected to calculate the association between variables. Furthermore, the odds ratio was calculated to measure the effect size of the categorical data (Field, 2013).

Table 8 shows that the null hypothesis was satisfied by health and safety and professional ethics $(p>0.05)$. However, significant differences are found for training, users' impact, and local criteria, whose odds ratios reveal the importance of these groups of criteria in ASCs with respect to SSCs (training: 6.098; users' impact: 5.875; and local: 10.181); therefore, these results confirm the distinction between ASCs and SSCs presented in Figure 6. 
Table 8. Odds ratios for groups of countries.

\begin{tabular}{cccccccc}
\hline SSCs - ASCs & Cultural Heritage & Employment & Health and Safety & Local & Professional Ethics & Training & Users' Impact \\
\hline$\chi^{2}$ & 9.001 & 10.572 & 1.068 & 107.062 & 1.015 & 77.886 & 75.792 \\
\hline Degrees of freedom & 1 & 1 & 1 & 1 & 1 & 1 & 1 \\
\hline Approx. Sig. (p) & 0.003 & 0.001 & 0.301 & 0.000 & 0.314 & 0.000 & 0.000 \\
\hline Phi & 0.141 & 0.153 & - & 0.487 & - & 0.416 & 0.410 \\
\hline Odd Ratio & 1.931 & 1.877 & - & 10.181 & - & 6.098 & 5.875 \\
\hline
\end{tabular}

Finally, to analyze the significant differences that could be found within of each group of countries, the ASCs and SSCs were assessed independently (Table 9). For this analysis, the chi-square $\left(\chi^{2}\right)$ contingency table analysis was applied. In case the variable was dependent, contingency coefficients (CC) were calculated for each pair of variables because the categorical variables have more than two dimensions (six dimensions for SSCs and four dimensions for ASCs). This coefficient allows determining how strongly the categorical variables are associated through its comparison with the maximum contingency coefficients $\left(C C_{\max }\right)$. Based on the ratio between $C C$ and $C C_{\max }$, the different levels of dependence can show strong dependence when $C C / C C_{\max } \geq 0.7$, moderate dependence when $0.5 \leq C C / C C_{\max }<0.7$, and low dependence when $C C / C C_{\max }<0.5$ (Field, 2013).

Table 9. Contingency coefficient for each group of countries.

\begin{tabular}{|c|c|c|c|c|c|c|c|c|}
\hline & & $\begin{array}{l}\text { Cultural } \\
\text { Heritage }\end{array}$ & Employment & $\begin{array}{c}\text { Health and } \\
\text { Safety }\end{array}$ & Local & $\begin{array}{l}\text { Professional } \\
\text { Ethics }\end{array}$ & Training & $\begin{array}{l}\text { Users' } \\
\text { Impact }\end{array}$ \\
\hline \multirow{5}{*}{ ASC } & $\chi^{2}$ & 3.242 & 31.846 & 18.955 & 16.904 & 99.0933 & 11.98 & 20.083 \\
\hline & Degrees of freedom & 3 & 3 & 3 & 3 & 3 & 3 & 3 \\
\hline & Approx. Sig. $(p)$ & 0.356 & 0.000 & 0.000 & 0.001 & 0.000 & 0.007 & 0.000 \\
\hline & Contingency coefficient (CC) & - & 0.401 & 0.32 & 0.304 & 0.613 & 0.259 & 0.329 \\
\hline & $C C / C C_{\max }$ & - & 0.57 & 0.45 & 0.43 & 0.86 & 0.37 & 0.47 \\
\hline \multirow{5}{*}{ SSC } & $\chi^{2}$ & 13.615 & 43.683 & 17.685 & $\begin{array}{c}112.48 \\
6\end{array}$ & 35.988 & 41.619 & 6.479 \\
\hline & Degrees of freedom & 5 & 5 & 5 & 5 & 5 & 5 & 5 \\
\hline & Approx. Sig. (p) & 0.018 & 0.000 & 0.003 & 0.000 & 0.000 & 0.000 & 0.262 \\
\hline & Contingency coefficient (CC) & 0.281 & 0.464 & 0.316 & 0.644 & 0.430 & 0.455 & - \\
\hline & $C C / C C_{\max }$ & 0.40 & 0.66 & 0.45 & 0.91 & 0.61 & 0.64 & - \\
\hline
\end{tabular}

The $C C_{\max }$ was 0.707 for all the analyzed scenarios. The results showed that, in ASCs, the dependence on training, health and safety, and users' impact was low. Only the consideration of cultural heritage did not differ significantly ( $p>0.05$ ), demonstrating similar patterns for these social criteria. In ASCs, cultural heritage is normally used in 35\% of their tenders. However, strong dependence has been observed with respect to professional ethics $\left(C C / C C_{\max }=0.85\right)$ since the USA and the UK tend to consider this category of criteria in more than $80 \%$ of the tenders, in contrast to the rest of the countries, which considered it in less than $20 \%$ of the tenders. With respect to employment, moderate dependence has been revealed within the ASCs. Regarding Australia, the results showed that this country strongly promotes the use of local and employment criteria. Canada presents a low use of professional ethics criteria. This result can be compared with that of Ruparathna and Hewage (2015), who highlighted that fair wages to the workers in the construction industry was considered in $4 \%$ of their documents, whereas, in this study, it was $6 \%$. Thus, the behavior is similar, which may show low growth with respect to 2013. If this country is compared with the rest of the ASCs, Canada is behind these countries in terms of employment and professional ethics. However, regarding cultural heritage, users' impact, and training, Canada is on a similar level with respect to the ASCs. 
The SSCs present similar behavior concerning users' impact $(p=0.073)$. This indicates that this category of criteria tends to be considered in only approximately $20 \%$ of their tenders. Cultural heritage and health and safety showed low significant differences. Employment, professional ethics, and training revealed a moderate level of dependence. The results show that Spain is encouraging the inclusion of employment and professional ethics. This trend has been followed by Chile who considers these criteria at a similar percentage. Argentina does not consider employment, and the percentage of inclusion of users' impact and professional ethics is lower than $10 \%$. Peru only considers health and safety in their tenders, considering the training and users' impact criteria at a lower level. This behavior is similar to Panama, which has only considered health and safety in their tenders.

The strong significant difference that has been found with respect to local criteria exists because, in general, the SSCs do not consider local criteria in more than $10 \%$ of their tenders, except for Colombia, which considered local criteria in $100 \%$ of their tenders in the category of projects between $1 \mathrm{M} €$ and $10 \mathrm{M} €$ and unspecified projects.

\section{Discussion}

This section discusses the results. Three subsections have been established to discuss the results related to each one of the research questions.

\subsection{What Are the Main Social Criteria? (Q1)}

Three levels can be distinguished to feature social criteria in public procurement of the construction industry at the international level. These three levels are established based on the frequency of consideration of social criteria in the analyzed tendering documents. The first and most important level is formed by health and safety criteria. As Reyes et al. (2014) remarked, the incorporation of health and safety criteria in construction projects improves working conditions, minimizes accident rates, and reduces project costs. This knowledge seems to have been accepted by procurers at the international level because indicators associated with this group of criteria appear in approximately $100 \%$ of the analyzed sample. This represents its strong acceptance at the international level. Within this group, indicators related to the development of workplace health and safety management plans and to ensuring public safety are the most frequently considered.

The second level gathers employment, users' impact, professional ethics, and training criteria. McCrudden (2004) remarked that public procurement can be used to enforce anti-discrimination law in the employment context and to boost the recruitment of disadvantaged groups. Employment of vulnerable groups has been one of the most frequently used indicators within the group of employment criteria. However, sub-categories of social indicators, such as job stability and industry participation plans, were included in very low percentages, despite that the enhancement of employment stability is the key to improve sustainable development (Pellicer et al., 2016) and that Burke and King (2015) remarked on the importance of SMEs in developing the social value of the construction industry. On the other hand, regarding the use of professional ethics criteria, strong efforts are needed. None of the categories of indicators in this group are over $30 \%$ in the frequency of occurrence. The consideration of indicators, such as non-discriminatory hiring practices and fair wages, has been scarce. Although gender equality has been the most considered within this group, it has been included in less than $28 \%$ of the analyzed 
samples. These results are important, considering that the construction industry is still a notably maledominated industry where only $12 \%$ of professional construction roles (such as architect, quantity surveyor, and engineer) are women and where concerns such as unemployment, low pay, and the gender pay gap are important issues that need to be addressed (Wright, 2015).

Indicators for training of workers and minimizing mobility disruption have risen to prominence in some of the analyzed countries, such as Australia or Canada. As Akenroye (2013) remarked, public procurement can create skill development, and requiring training programs in procurement procedures can boost suppliers' understanding of social issues. Additionally, the effect on the community due to the work development is an important aspect that needs to be considered in the design and planning stages (ISI, 2015).

Finally, the third level comprises local and cultural heritage criteria. The results showed a lack of cultural heritage criteria in most of the countries, positioning it as the least considered criteria. This fact shows the lack of awareness about the relevance of these criteria in tendering procedures, considering that cultural heritage is essential to uphold fundamental human rights and respect the customs and values of communities (Akinwunmi, 2014). This is an strategic factor in the promotion of local economic development (Guccio et al., 2014). Finally, local criteria present wide variability in the obtained results. Some countries such as Colombia, the United States, Australia, and the United Kingdom are aware of the importance of including local criteria in the procurement procedures to mediate equity concerns and economic and social development (Kaye et al., 2012); however, these criteria are rarely considered in countries such as Spain, Chile, Argentina, or Peru whose economic scenarios in recent years have encouraged the presence of social conflicts associated with the construction industry (Fontana et al., 2017; Palomares et al., 2017).

\subsection{How Are Social Criteria Defined? (Q2)}

It is generally accepted that indicators should be specifically designed to promote the implementation of better practices and to demonstrate the progress being made (CIRIA, 2001). However, there seems to be a lack of understanding regarding how to include metrics to make indicators quantifiable for bid evaluation in construction public procurement (Molenaar et al., 2010). As shown in the results, this malpractice encompasses the inclusion of social criteria in the tendering procedures of the construction industry (Ruparathna and Hewage, 2015) since less than 20\% of indicators gathered in the analyzed sample were metrics. The main categories of indicators considered with metrics have been associated with the inclusion of professionals in terms of cultural heritage or health and safety, the requirement of occupational health and safety certifications, job stability, employment of vulnerable groups, and gender equality. Nevertheless, categories of indicators, such as workplace health and safety management plans, technical and sustainability training of workers, minimization of the harm done to the neighborhood or the existing services, industry participation plans, and employment created or retained, were characterized by a lack of metrics to be assessed. This fact implies that the uncertainty and complexity of assessing social criteria and measuring the performance is one of the main barriers affecting the effective implementation of social sustainability in the construction industry (Sutherland et al., 2015), and it hinders the compliance of clients' needs and the achievement of socially sustainable objectives (Bruno et al., 2018).

Page $\mathbf{2 2}$ of $\mathbf{3 7}$ 
Sutherland et al. (2015) noted that social requirements in construction procurement potentially affect processes and management systems and have important implications for both procuring organizations and suppliers. In line with this, the results highlight a wide variability in the inclusion of social criteria at the international level. However, the results show that there is an important increase in the inclusion of social indicators as the budget size of projects increases. This trend is common for each one of the analyzed social criteria, except for local criteria, which suffer an opposite tendency and tend to be included as the budget size of projects decreases. Based on the European Commission (2010), an effective way to promote local SMEs is giving them greater access to public procurement, ensuring contracts for which size is not an obstacle in itself to their participation.

Regarding the inclusion of metrics, the results show strong differences since a lack of awareness of the need for metrics to measure social sustainability has been found regardless of the contract duration or the contract size. Thus, although it seems that procurers are more conscious about the necessity of including social indicators in construction public procurement, there is a need associated with the inexperience of procurers to include quantitative indicators in procurement procedures (Sourani and Sohail, 2011).

\subsection{Do Significant Differences Between Countries Exist Regarding Including Social Criteria in Tendering Procedures at the International Level? (Q3)}

The dependent relation between the social criteria and the analyzed countries implies a clear distinction in two groups of countries: the group formed by ASCs comprising Australia, Canada, the UK, and the USA and the group formed by SSCs comprising Argentina, Chile, Colombia, Panama, Peru, and Spain. These groups have similarities, such as the notable use of health and safety criteria. However, two main features imply the need to differentiate them. First, the inclusion of local, training, and users' impact criteria is considerably greater for ASC compared to SSC. These differences are on the order of 10, 6, and 6 times, respectively, since these criteria are hardly considered in SSCs. Second, SSCs show a lower percentage of inclusion for each one of the analyzed social criteria with respect to ASCs. McCrudden (2004) highlighted that the use of public procurement to put social policies into effect has a long history in countries such as the USA or the UK. Additionally, along the years, the experience of these countries has had a strong influence on countries like Canada and Australia. However, researchers such as Taylor et al. (2013), Revington et al. (2015), and the United Nations (2008) analyzed the inclusion of social aspects in public procurement of Latin American countries, and these noted that social sustainability has not been a priority for these countries until now. It is only recently that countries such as Chile, Colombia, and Brazil have been boosting measures for using public procurement to support local industries and to increase participation of small businesses.

Regarding the study of the relation between the countries of the ASC group, similar patterns were found for cultural heritage criteria, presenting a low consideration in their tendering documents. However, minor differences are highlighted with respect to training, health and safety, users' impact, local, and employment criteria, while the differences associated with professional ethics are strong, especially due to the high consideration of this type of criteria in countries such as the USA and the UK. The USA and the UK are countries that include professional ethics criteria in social procurement the most, intending to overcome important issues focused on discrimination and racism (McCrudden, 2004). The USA is mainly focused on indicators associated with gender equality and fair wages for construction workers. However, 
the UK is more involved with indicators related to non-discriminatory hiring practices and avoiding corruption. Moreover, the USA is the ASC that considers employment criteria the most by including industry participation plans and the employment of the vulnerable population in $60 \%$ of their tenders. This was noted by Loosemore (2015) who emphasized the effort that this country is making to employ minorities in business. Australia, however, is more focused on the creation and maintenance of employment. Additionally, Australia is strongly promoting the use of local and employment criteria and is encouraging indigenous opportunity policies and improving opportunities for local people with limited employment and training opportunities (Barraket and Weissman, 2009; Petersen and Kadefors, 2016). Furthermore, SPAG (2012) stated that Australia has implemented policies to enhance opportunities for Australian SMEs to win government contracts. State governments and departments have inserted social procurement guidelines or policies into their procurement processes, requiring that procurement officers consider social benefits when awarding contracts (Burkett, 2010; SPAG, 2012).

On the other hand, Canada is the most aware country regarding the importance of cultural heritage, and it includes this social category in 50\% of their analyzed tenders. Regarding users' impact and training, Canada is on a similar level with respect to the ASCs; however, this country is behind the rest of the ASCs in terms of employment and professional ethics. Revington et al. (2015) affirmed that Canada has been slow with respect to the rest of the ASCs in adopting social procurement. Thus, it developed the “2013-16 Federal Sustainability Strategy” to promote social goals in public procurement and to increase employment and local development.

The comparison between the countries gathered in SSCs group show that there is a lack of consideration of users' impact criteria in these countries. Regarding the inclusion of cultural heritage and health and safety criteria in tendering documents, results show low significant differences. For employment, professional ethics, and training, the results revealed a moderate level of dependence. However, a strong significant difference has been found with respect to local criteria. As Loosemore (2015) stated, due to EU directives, Spain is currently encouraging the inclusion of employment and professional ethics, having started to show an unwavering commitment toward sustainability from governmental initiatives in recent years (Reverte, 2015). Regarding employment criteria, Spain has mainly focused its effort on encouraging job stability and the employment of the vulnerable population. Moreover, concerning professional ethics, Spain is only interested in gender equality criteria, disregarding the rest of the professional ethics criteria. Both results are a consequence of the economic scenario that the construction industry has experienced in recent years in this country (Palomares et al., 2017). Similar behavior has been observed for Chile, who considers both employment and professional ethics at a similar percentage. However, employment criteria in Chile are focused on the creation and maintenance of employment and on encouraging the employment of the vulnerable population. Regarding professional ethics, the indicators are centered on gender equality). This behavior has been encouraged by the Chilean Government, which elaborated responsible public purchasing policies to promote the three dimensions of sustainability in 2012 (UNEP, 2013).

On the other hand, Argentina does not consider employment, and the percentage of inclusion of users' impact and professional ethics is lower than $10 \%$. Peru only considers health and safety in their tenders, considering training and users' impact criteria at a lower level. This was claimed by AECID (2016) who noted the lack of consideration of local aspects in Peru's tenders and emphasized that, regarding social 
sustainability, this country is primarily focused on improving health and safety performance. This behavior is similar to Panama, which has only considered health and safety in their tenders, in line with the comments of Taylor et al. (2013) about sustainability in the construction industry of Latin America and the Caribbean countries.

In general, the SSCs do not consider local criteria in more than $10 \%$ of their tenders, except for Colombia, which presented a high percentage of inclusion of this type of criteria. The AECID (2016) conducted an analysis of a group of tendering documents from different Latin American countries in the construction industry, concluding that there is a high degree of consideration of social criteria in the tendering procedures of Colombia, especially with those criteria related to increasing local employment. This is the result of the Colombia Government, which, in 2011, boosted requirements that national procurers include measures to promote local participation in their tendering procedures.

\section{Conclusions}

\subsection{Contributions}

This paper studies the inclusion of social criteria in public procurement in the construction industry at the international level. Ten countries are analyzed through the compilation of 451 tendering documents. To go one step further with respect to the existing literature and to show a comparative study that would allow achieving a general vision of social sustainability in the public procurement of the construction industry, this research seeks to analyze what the main social criteria are and how these are defined in public works procurement. Then, significant variations between countries are assessed to identify differences and similarities within the sample.

Through a literature review, eight categories of social criteria were established: cultural heritage, employment, health and safety, local, professional ethics, public participation, training, and users' impact. Through a content analysis, 2,724 social indicators were identified and gathered in 23 sub-categories. Descriptive statistics and statistical analyses were developed to analyze the gathered data. Countries such as the USA, the UK, and Australia include social categories the most. However, the results show that the lack of objective methods to assess the social sustainability in public-work procurement is common in every analyzed country. The assessment of the variability associated with the percentage of inclusion of each group of social criteria in each of the countries has shown that, except health and safety, a wide variability exists with respect to the inclusion of social criteria. Cultural heritage and local criteria are the least considered social criteria at the international level. However, the distribution is influenced by the contract size of the project.

The comparison between countries has revealed two groups of countries that are clearly differentiated: the group formed by ASCs comprising Australia, Canada, the United Kingdom, and the United States and the group formed by SSCs comprising Argentina, Chile, Colombia, Panama, Peru, and Spain. Although both groups have similarities, such as the notable use of health and safety criteria, the main differences between these groups are associated with the consideration of the users' impact and training criteria and the percentage of inclusion of the rest of the social criteria. Additionally, within each group, important differences are found based on the use of professional ethics and employment criteria. In this regard, 
Colombia, Spain, and Chile within the SSCs and the USA and the UK within the ASCs were the countries that most considered these criteria.

Differences and similitudes were assessed within each group of countries through the contingency table analysis. The ASCs present a better performance than SSCs because they include every social criterion more frequently than the SSCs. Regarding ASCs, professional ethics is widely considered by the USA and the UK; however, slight similarities have been found within the group of ASCs regarding employment, health and safety, training, and users' impact. In contrast, the group formed by SSCs tends to not consider users' impact criteria in their tendering documents. In terms of cultural heritage and health and safety criteria, SSCs do not show significant differences. Nevertheless, a strong significant difference has been identified regarding local criteria because Colombia differs significantly from the rest of the SSCs. Similarly, Canada must improve the performance to approach the results of countries such as the UK and the USA.

Finally, regarding the highest inclusion of each social category per country: employment is mainly considered in tendering documents from the USA and Spain. Training criteria are frequently included in countries such as Canada, Australia, and the USA. Local criteria are highlighted at the first level in Colombia and, at the second level, in Australia, the USA, and the UK. Professional ethics criteria appear mainly in tendering documents from the USA, the UK, and Colombia. Meanwhile, users' impact is frequently considered in Australia. Regarding cultural heritage criteria, these criteria are less considered than the rest of the social categories; however, Canada is the country that considers cultural heritage criteria the most ( $50 \%$ of their analyzed tenders).

\subsection{Implications for Theory and Practice on Sustainability}

The work we have developed in this research offers an international view of the current performance of construction public procurement regarding the inclusion of social criteria, analyzing how procurers manage this dimension of sustainability in tendering documents. This characterization work is the basis to know and understand the problem and is the motivation to develop actions that effectively work to address particular needs associated with the context of the study.

Important implications stand out in this research. Eight categories of social criteria (cultural heritage, employment, health and safety, local, professional ethics, public participation, training, and users' impact) are the minimum group of social criteria that should be considered when the study of social sustainability in the construction industry wants to be performed. The variable "country" highlights showing a significant influence over the inclusion of social criteria in public procurement at the international level. The consideration of this variable is essential when the social sustainability of construction projects is to be compared at the international level. Additionally, differentiation between ASCs and SSCs must be considered to develop an international assessment of social sustainability because, regarding sustainability, their cultural history and current performance make them sufficiently dissimilar to be distinguished. On the other hand, results show that social criteria are generally considered in public procurement procedures of the construction industry; however, the efforts of public agencies at the international level seem to have focused only on boosting the inclusion of health and safety criteria since this is the only group of criteria that appears in practically $100 \%$ of the analyzed sample. Thus, major 
efforts are needed to encourage the consideration of the rest of the social criteria groups to try to achieve the integration of all of them in each construction contract. Finally, it is important to emphasize that, to achieve a sustainable production in the construction industry, setting social criteria to cover each social category is needed in addition to defining the metrics to assess these criteria quantitatively to control the proper performance of construction companies and monitor the achievement of social outcomes in construction projects.

Therefore, to overcome the existing shortcomings, strong social policies should be implemented to promote the use of social criteria in the award of projects. For both developing and developed countries, performance indicators need to be defined, and strong implications of public agencies are required for the evaluation and monitoring of social performance in the construction industry. Additionally, the best practices should be further implemented through training and workshops in as many tendering organizations as possible. A guide defining different social indicators associated with metrics should be defined, considering the different types of projects, infrastructures, delivery systems, procurement procedures, etc. One suggestion that would address this issue is that public agencies should study their social deficiencies and propose social criteria to accomplish their goals. Finally, each project should publicly show the objectives of social indicators associated with the work and the final results achieved to increase the awareness for both companies and the population.

\subsection{Limitations}

Regarding the limitations of this study, the data collection was based only on those documents that were available free online in the public procurement Internet websites of each country. Tendering documents are mainly from national or regional agencies, which notably reduced the number of documents from local authorities. Although the searches of the government procurement sites were largely consistent, it is possible that some tendering documents were mischaracterized, excluding them from the search results. Thus, this study cannot claim a truly random sample. However, these limitations are also shared by other studies based on the content analyses of tendering documents.

\subsection{Future Research}

Future research is needed to analyze how social criteria are considered at the international level, depending on aspects such as the different phases of the tendering procedure, the delivery system, the type of civil infrastructures, and so on. Additionally, a joint analysis of the inclusion of social and environmental criteria in procurement procedures and assessing the weights that are given for these criteria in the award phase of the tendering procedure should be conducted. These studies will offer understanding of the role that each dimension plays to achieve sustainability in public procurement of the construction industry. Defining performance indicators will allow the assessment of the social performance of infrastructure projects using objective methods. Furthermore, in-depth studies are needed to analyze the real effects that the inclusion of social aspects in the tendering procedure have on the social environment.

\section{Acknowledgements}

Page $\mathbf{2 7}$ of $\mathbf{3 7}$ 
The authors acknowledge the financial support of the Spanish Ministry of Economy and Competitiveness, along with FEDER funding (Project: BIA2017-85098-R).

\section{References}

Abdel-Raheem, M., Ramsbottom, C., 2016. Factors Affecting Social Sustainability in Highway Projects in Missouri. Procedia Eng. 145, 548-555. https://doi.org/10.1016/j.proeng.2016.04.043

Adetunji, I., Price, A., Fleming, P., Kemp, P., 2003. Sustainability and the UK Construction Industry-A review. Proc. Inst. Civ. Eng. - Eng. Sustain. 156, 185-199.

https://doi.org/https://doi.org/10.1680/ensu.2003.156.4.185

Adham, N.K., Siwar, C., 2012. Empirical Investigation of Government Green Procurement (GGP) Practices in Malaysia. OIDA Int. J. Sustain. Dev. 05(08), 41-50.

AECID, 2016. Study about Social and Environmental Requirements in Tendering Documents from Latin American and Caribbean (Estudio sobre los requisitos sociales y medioambientales en licitaciones públicas de america latina y caribe), Agencia Española de Cooperación Internacional para el Desarrollo. España.

Akenroye, T.O., 2013. An Appraisal of the Use of Social Criteria in Public Procurement in Nigeria. J. Public Procure. 13, 364-397. https://doi.org/10.1108/JOPP-13-03-2013-B005

Akiwumi, F.A., 2014. Strangers and Sierra Leone mining: cultural heritage and sustainable development challenges. J. Clean. Prod. 84, 773-782. https://doi.org/10.1016/j.jclepro.2013.12.078

Amiril, A., Nawawi, A.H., Takim, R., Latif, S.N.F.A., 2014. Transportation Infrastructure Project Sustainability Factors and Performance. Procedia - Soc. Behav. Sci. 153, 90-98. https://doi.org/10.1016/j.sbspro.2014.10.044

Andrecka, M., 2017. Corporate Social Responsibility and Sustainability in Danish Public Procurement. Eur. Procure. Public Priv. Partnersh. Law Rev. 12, 333-345. https://doi.org/http://dx.doi.org/10.21552/epppl/2017/3/14

Arce, R., Gullón, N., 2000. The application of Strategic Environmental Assessment to sustainability assessment of infrastructure development. Environ. Impact Assess. Rev. 20, 393-402.

Azapagic, A., Perdan, S., 2000. Indicators of Sustainable Development for Industry: A General Framework. Inst. Chem. Eng. Trans IChemE 78, 243-261. https://doi.org/0957 $\pm 5820 / 00 / \$ 10.00+0.00$

Balubaid, S., Bujang, M., Nur Aifa, W., Kian Seng, F., Raja Muhammad Rooshdi, R.R., Hamzah, N., Mohd Yazid, Y.S., Abd. Majid, M.Z., Mohamad Zin, R., Zakaria, R., Hainin, M.R., Yaacob, H., Ismail, H.H., 2015. Assessment Index Tool for Green Highway in Malaysia. J. Teknol. 77, 99-104. https://doi.org/10.11113/jt.v77.6405

Barraket, J., Weissman, J., 2009. Social Procurement and its Implications for Social Enterprise : a literature review [Working Paper No. CPNS48]. The Australian Centre for Philanthropy and Nonprofit Studies, Brisbane.

Beiler, M.R.O., Treat, C., 2015. Integrating GIS and AHP to Prioritize Transportation Infrastructure Using Sustainability Metrics. J. Infrastruct. Syst. 21, 04014053. 
https://doi.org/10.1061/(ASCE)IS.1943-555X.0000245.

Bovaird, T., 2006. Developing New Forms of Partnership with the "market" in the Procurement of Public Services. Public Adm. 84, 81-102. https://doi.org/10.1111/j.0033-3298.2006.00494.x

Brammer, S., Walker, H., 2011. Sustainable Procurement in the Public Sector : an International Comparative Study. Int. J. Oper. Prod. Manag. 31, 452-476.

https://doi.org/10.1108/01443571111119551

Bratt, C., Hallstedt, S., Robert, K., Broman, G., Oldmark, J., 2013. Assessment of criteria development for public procurement from a strategic sustainability perspective. J. Clean. Prod. 52, 309-316. https://doi.org/10.1016/j.jclepro.2013.02.007

Brown, K., Furneaux, C., Gudmundsson, A., 2012. Infrastructure Transitions towards Sustainability : a Complex Adaptive Systems Perspective. Int. J. Sustain. Dev. 15, 54-71. https://doi.org/http://dx.doi.org/10.1504/IJSD.2012.044034

Bruno, T., Gelderman, C.J., Lambrechts, W., Semeijn, J., 2018. The promise of Best Value Procurement: Governance and (in)stability of specifications within an innovative biogas project. J. Clean. Prod. 172, 1465-1475. https://doi.org/10.1016/j.jclepro.2017.10.251

Bryman, A., 2012. Social research methods. Oxford University Press. https://doi.org/10.1017/CBO9781107415324.004

Burke, C., King, A., 2015. Generating Social Value through Public Sector Construction Procurement: a Study of Local Authorities and SMEs. Raidén, A B Aboagye-Nimo, E Procs 31st Annu. ARCOM Conf. 7-9 Sept. 2015, Lincoln, UK, Assoc. Res. Constr. Manag. 387-396.

Burkett, I., 2010. Social Procurement in Australia: A Compendium of Case Studies. Sydney, Australia. The Centre for Social Impact, University of NSW.

Carnevalli, J.A., Miguel, P.C., 2008. Review, Analysis and Classification of the Literature on QFD-Types of Research, Difficulties and Benefits. Int. J. Prod. Econ. 114, 737-754. https://doi.org/10.1016/j.ijpe.2008.03.006

Carter, K., Fortune, C., 2007. Sustainable Development Policy Perceptions and Practice in the UK Social Housing Sector. Constr. Manag. Econ. 25, 399-408. https://doi.org/10.1080/01446190600922578

CEEQUAL, 2010. CEEQUAL. The Assessment and Awards Scheme for improving sustainability in civil engineering and the public realm.

CIRIA, 2001. Sustainable Construction Company Indicators. Construction Industry Research adn Information Association (CIRIA).

Cohen, J., 1960. A Coefficient of Agreement for Nominal Scales. Educ. Psychol. Meas. 20, 37-46. https://doi.org/10.1177/001316446002000104

De Gisi, S., Casella, P., Sabia, G., Farina, R., Landolfo, P., Notarnicola, M., De Feo, G., 2017. Assessing the Public Perception of Islanders regarding the Implementation ofNew Technologies to Optimize the Municipal Solid Waste Management System: A Mediterranean Case Study. J. Clean. Prod. 164, 1586-1601. https://doi.org/10.1016/j.jclepro.2017.07.090

Dobrovolskiien, N., Tamošiluniene, R., 2016. An Index to Measure Sustainability of a Business Project in 
the Construction Industry : Lithuanian Case. Sustainability 8, 1-14.

https://doi.org/10.3390/su8010014

Ekener, E., Hansson, J., Larsson, A., Peck, P., 2018. Developing Life Cycle Sustainability Assessment methodology by applying values-based sustainability weighting - Tested on biomass based and fossil transportation fuels. J. Clean. Prod. 181, 337-351. https://doi.org/10.1016/j.jclepro.2018.01.211

Essl, I., Mauerhofer, V., 2018. Opportunities for mutual implementation of nature conservation and climate change policies: A multilevel case study based on local stakeholder perceptions. J. Clean. Prod. 183, 898-907. https://doi.org/10.1016/j.jclepro.2018.01.210

European Commission, 2010. Buying Social. A Guide to Taking Account of Social Considerations in Public Procurement, Contract Management. https://doi.org/978-92-79-18738-4

Faith-Ell, C., Balfors, B., Folkeson, L., 2006. The application of environmental requirements in Swedish road maintenance contracts. J. Clean. Prod. 14, 163-171. https://doi.org/10.1016/j.jclepro.2004.11.004

Fernández-Sánchez, G., Rodríguez-López, F., 2010. A Methodology to Identify Sustainability Indicators in Construction Project Management - Application to Infrastructure Projects in Spain. Ecol. Indic. 10, 1193-1201. https://doi.org/10.1016/j.ecolind.2010.04.009

FHWA-INVEST, 2012. Sustainable Highways Self-Evaluation Tool [WWW Document]. Invest 1.0. URL https://www.sustainablehighways.org/INVEST_1.0_Compendium_Web.pdf (accessed 10.10.16).

FIDIC, 1999. Condition of Contract for Construction. International Federation of Consulting Engineers. Geneva. Switzerland.

Field, A., 2013. Discovering statistics using IBM SPSS Statistics. SAGE Publications, Los Angeles.

Fontana, A., Sastre-Merino, S., Baca, M., 2017. The Territorial Dimension: The Component of Business Strategy that Prevents the Generation of Social Conflicts. J. Bus. Ethics 141, 367-380. https://doi.org/10.1007/s10551-015-2712-3

Fuentes-Bargues, J., González-Cruz, M., González-Gaya, C., 2017. Environmental Criteria in the Spanish Public Works Procurement Process. Chakraborty J, ed. Int. J. Environ. Res. Public Heal. 14. https://doi.org/10.3390/ijerph14020204

Gransberg, D.D., Barton, R.F., 2007. Analysis of Federal Design-Build Request for Proposal Evaluation Criteria. J. Manag. Eng. 23, 105-111. https://doi.org/10.1061/(ASCE)0742-597X(2007)23:2(105)

GRI, 2011. , Sustainability Reporting Guidelines. (C) 2000-2011 GRI Version 3.1. Amsterdam, Netherlands.

Guccio, C., Pignataro, G., Rizzo, I., 2014. Evaluating the Efficiency of Public Procurement Contracts for Cultural Heritage Conservation Works in Italy. J. Cult. Econ. 38, 43-70. https://doi.org/10.1007/s10824-012-9194-2

Hair, J.F., Black, W.C., Babin, B.J., Anderson, R.E., 2014. Multivariate Data Analysis: Pearson New International Edition Seventh edition. Pearson, Harlow, Essex (UK).

Hall, M., Purchase, D., 2006. Building or bodging? Attitudes to sustainability in UK public sector 
housing construction development. Sustain. Dev. 14, 205-218. https://doi.org/10.1002/sd.265

Harmer, C., Harris, B., Hewitt, A., Woodward, R., 2012. SUNRA. Sustainability-National Road Administrations. Measures to Improve Sustainability.

Hong, D.Y., Ng, S.T., 2015. A Life Cycle Assessment Model for Evaluating the Environmental Impacts of Building Construction in Hong Kong. Build. Environ. 89, 183-191.

https://doi.org/10.1016/j.buildenv.2015.02.020

Hossain, M.U., Poon, C.S., Dong, Y.H., Lo, I.M.C., Cheng, J.C.P., 2017. Development of Social Sustainability Assessment Method and a Comparative Case Study on Assessing Recycled Construction Materials. Int. J. Life Cycle Assess. https://doi.org/10.1007/s11367-017-1373-0

Hosseinijou, S.A., Mansour, S., Shirazi, M.A., 2014. Social Life Cycle Assessment for Material Selection: A Case Study of Building Materials. Int. J. Life Cycle Assess. 19, 620-645. https://doi.org/10.1007/s11367-013-0658-1

Hsieh, H.-F., Shannon, S.E., 2005. Three Appraoches to Qualitative Content Analysis. Qual. Health Res. 15, 1227-1288. https://doi.org/10.1177/1049732305276687

Hueskes, M., Verhoest, K., Block, T., 2017. Governing Public-Private Partnerships for Sustainability: An Analysis of Procurement and Governance Practices of PPP Infrastructure Projects. Int. J. Proj. Manag. 35, 1184-1195. https://doi.org/10.1016/j.ijproman.2017.02.020

ISI, 2015. ENVISION Rating System For Sustainable Infrastructure [WWW Document]. Inst. Sustain. Infrastruct. URL https://sustainableinfrastructure.org/portal/files/GuidanceManual.pdf (accessed 1.10.17).

Jato-Espino, D., Castillo-Lopez, E., Rodriguez-Hernandez, J., Canteras-Jordana, J.C., 2014. A Review of Application of Multi-Criteria Decision Making Methods in Construction. Autom. Constr. 45, 151162. https://doi.org/10.1016/j.autcon.2014.05.013

Jelodar, M.B., Yiu, T.W., Wilkinson, S., 2017. Assessing Contractual Relationship Quality: Study of Judgment Trends among Construction Industry Participants. J. Manag. Eng. 33, 04016028. https://doi.org/10.1061/(ASCE)ME.1943-5479.0000461

Jeon, C.M., Amekudzi, A., 2005. Addressing Sustainability in Transportation Systems : Definitions , Indicators , and Metrics. J. Infrastruct. Syst. 11, 31-50.

Kahlenborn, W., Moser, C., Frijdal, J., Essig, M., 2010. Strategic Use of Public Procurement in Europe Financed by : European Commission. Final Report to the European Commission MARKT/2010/02/C. Berlin: adelphi.

Kaye, L., Gabriela, N., Nijaki, L.K., 2012. Procurement for Sustainable Local Economic Development. Int. J. Public Sect. Manag. 25, 133-153. https://doi.org/10.1108/09513551211223785

Kenny, C., 2007. Construction, Corruption, and Developing Countries, Working Paper No. 4271, World Bank Policy Research, The World Bank, Washington, DC, pp.

Khalili-Damghani, K., Tavana, M., 2014. A Comprehensive Framework for Sustainable Project Portfolio Selection Based on Structural Equation Modeling. Proj. Manag. J. 45, 83-97. https://doi.org/10.1002/pmj 
Kippo-Edlund, P., Hauta-Heikkilä, H., Miettinen, H., Nissinen, A., 2005. Measuring the Environmental Soundness of Public Procurement in Nordic Countries. TermaNord, 505, Nord. Counc. Minist. Copenhagen.

Krajangsri, T., Pongpeng, J., 2017. Effect of Sustainable Infrastructure Assessments on Construction Project Success Using Structural Equation Modeling. J. Manag. Eng. 33. https://doi.org/10.1061/(ASCE)ME.1943-5479.0000509.

Kylili, A., Fokaides, P.A., Amparo, P., Jimenez, L., 2016. Key Performance Indicators ( KPIs ) Approach in Buildings Renovation for the Sustainability of the Built Environment: A review. Renew. Sustain. Energy Rev. 56, 906-915. https://doi.org/10.1016/j.rser.2015.11.096

Li, H., Zhang, X., Ng, S.T., Skitmore, M., 2018. Quantifying Stakeholder Influence in Decision/Evaluations Relating to Sustainable Construction in China - A Delphi approach. J. Clean. Prod. 173, 160-170. https://doi.org/10.1016/j.jclepro.2017.04.151

Lim, S.K., 2009. Framework and Processes for Enhancing Sustainability Deliverables in Australian Road Infrastructure Projects. Queensland University of Technology.

Lines, B., Miao, F., 2016. Writing More Competitive Proposals: Content Analysis of Selected (and Unselected) Construction Contractor Technical Proposals, in: Construction Research Congress 2016: Old and New Construction Technologies Converge in Historic San Juan - Proceedings of the 2016 Construction Research Congress, CRC 2016. pp. 457-466.

Loosemore, M., 2016. Social Procurement in UK Construction Projects. Int. J. Proj. Manag. 34, 133-144. https://doi.org/10.1016/j.ijproman.2015.10.005

Loosemore, M., 2015. Building a New Third Construction Sector Through Social Enterprise. Constr. Manag. Econ. 6193. https://doi.org/10.1080/01446193.2015.1090006

McClave, J., Benson, P.G., Sincich, T., 2010. Statistics for Business and Economics, 11th Ed., Prentice Hall, Upper Saddle River, NJ.

McCrudden, C., 2004. Using Public Procurement to Achieve Social Outcomes. Nat. Resour. Forum 28, 257-267. https://doi.org/10.1111/j.1477-8947.2004.00099.x

Molenaar, K.R., Sobin, N., Antillón, E.I., 2010. A Synthesis of Best-Value Procurement Practices for Sustainable Design-Build Projects in the Public Sector. J. Green Build. 5, 148-157. https://doi.org/10.3992/jgb.5.4.148

Muench, S.T., Scarsella, M., Bradway, M., Hormann, L., Cornell, L., 2012. Evaluating Project-Based Roadway Sustainability Rating System for Public Agency Use. J. Transp. Res. Board 8-18. https://doi.org/10.3141/2285-02

Myers, D., 2013. Construction Economics: A New Approach. 3rd ed. Abingdon: Routledge.

Neuendorf, K.A., 2017. The Content Analysis Guidebook. Sage Publications, Thousand Oaks, CA.

Neuendorf, K.A., 2002. The Content Analysis Guidebook. Sage, Thousand Oaks. Sage Publications, Thousand Oaks, CA.

Nissinen, A., Parikka-Alhola, K., Rita, H., 2009. Environmental Criteria in the Public Purchases above the EU Threshold Values by Three Nordic Countries : 2003 and 2005. Ecol. Econ. 68, 1838-1849. 
https://doi.org/10.1016/j.ecolecon.2008.12.005

Oltean-Dumbrava, C., Watts, G.R., Hakim, A., Miah, S., 2014. “ Top-Down-Bottom-Up” Methodology as a Common Approach to Defining Bespoke Sets of Sustainability Assessment Criteria for the Built Environment. J. Manag. Engi- neering 30, 19-31. https://doi.org/10.1061/(ASCE)ME.19435479.0000169 .

Oswald, D., Sherratt, F., Smith, S., 2018. Problems with Safety Observation Reporting: A Construction Industry Case Study. Saf. Sci. 107, 35-45. https://doi.org/10.1016/j.ssci.2018.04.004

Palomares, R.C., Signes, E.S., Tiebas, J.J.P.T., 2017. The Importance of the Local in Crisis Situations the Study of the Province of Valencia 2007-2015 | [La importancia de lo local en situaciones de crisis el estudio de la provincia de Valencia 2007-2015].

Pan, L., 2015. Sustainability Study of Government Procurement of Public Services in Guangzhou — A Perspective Based on the Resources Dependence of Social Work. Open J. Soc. Sci. 3, 118-123. https://doi.org/http://dx.doi.org/10.4236/jss.2015.312012

Pardo-Bosch, F., Aguado, A., 2016. Sustainability as the Key to Prioritize Investments in Public Infrastructures. Environ. Impact Assess. Rev. 60, 40-51. https://doi.org/10.1016/j.eiar.2016.03.007

Pellicer, E., Sierra, L.A., Yepes, V., 2016. Appraisal of Infrastructure Sustainability by Graduate Students Using an Active-Learning Method. J. Clean. Prod. 113, 884-896. https://doi.org/10.1016/J.JCLEPRO.2015.11.010

Penadés-Plà, V., García-Segura, T., Matí, J. V., Yepes, V., 2016. A Review of Multi-Criteria DecisionMaking Methods Applied to the Sustainable Bridge Design. Sustainability 8, 1295. https://doi.org/10.3390/su8121295

Petersen, D., Kadefors, A., 2016. Social Procurement and Employment Requirements in Construction. P W Chan C J Neilson Proc. 32nd Annu. ARCOM Conf. 5-7 Sept. 2016, Manchester, UK, Assoc. Res. Constr. Manag. 2, 997-1006.

Pocock, J., Steckler, C., Hanzalova, B., 2016. Improving Socially Sustainable Design and Construction in Developing Countries. Procedia Eng. 145, 288-295. https://doi.org/10.1016/j.proeng.2016.04.076

Popovic, T., Barbosa-Póvoa, A., Kraslawski, A., Carvalho, A., 2018. Quantitative Indicators for Social Sustainability Assessment of Supply Chains. J. Clean. Prod. 180, 748-768. https://doi.org/10.1016/j.jclepro.2018.01.142

Rahdari, A.H., Anvary Rostamy, A.A., 2015. Designing a General Set of Sustainability Indicators at the Corporate Level. J. Clean. Prod. 108, 757-771. https://doi.org/10.1016/j.jclepro.2015.05.108

Reverte, C., 2015. The New Spanish Corporate Social Responsibility Strategy 2014-2020 : A Crucial Step Forward with New Challenges Ahead. J. Clean. Prod. ' 91, 327-336.

Revington, C., Hoogendam, R., Holeton, A., 2015. The Social Procurement Intermediary. The State of the Art and its Development within the GTHA [WWW Document]. URL http://lefca.org/documents/Social-Procurement-Intermediary-LEF-2015.pdf (accessed 7.4.17).

Reyes, J.P., San-josé, J.T., Cuadrado, J., Sancibrian, R., 2014. Health \& Safety Criteria for Determining the Sustainable Value of Construction Projects. Saf. Sci. 62, 221-232. 
https://doi.org/10.1016/j.ssci.2013.08.023

Rodrigues, M., Mendes, L., 2018. Mapping of the Literature on Social Responsibility in the Mining Industry: A Systematic Literature Review. J. Clean. Prod. 181, 88-101. https://doi.org/10.1016/j.jclepro.2018.01.163

Roman, A. V, 2017. Institutionalizing Sustainability : A Structural Equation Model of Sustainable Procurement in US Public Agencies. J. Clean. Prod. 143, 1048-1059. https://doi.org/10.1016/j.jclepro.2016.12.014

Ruparathna, R., Hewage, K., 2015. Sustainable Procurement in the Canadian Construction Industry: Current Practices , Drivers and Opportunities. J. Clean. Prod. 109, 305-314. https://doi.org/10.1016/j.jclepro.2015.07.007

Sarkis, J., Meade, L.M., Presley, A.R., 2012. Incorporating Sustainability into Contractor Evaluation and Team Formation in the Built Environment. J. Clean. Prod. 31, 40-53. https://doi.org/10.1016/j.jclepro.2012.02.029

Shen, L., Wu, Y., Zhang, X., 2011. Key Assessment Indicators for the Sustainability of Infrastructure Projects. J. Constr. Eng. Manag. 137, 441-451. https://doi.org/10.1061/(ASCE)CO.1943-7862

Shen, L.Y., Wu, Y.Z., Chan, E.H.W., Hao, J.L., 2005. Application of System Dynamics for Assessment of Sustainable Performance of Construction Projects 339-349. https://doi.org/10.1631/jzus.2005.A0339

Shiau, T.-A., Chuen-Yu, J.-K., 2016. Developing an Indicator System for Measuring the Social Sustainability of Offshore Wind Power Farms. sustainability 8, 470. https://doi.org/10.3390/su8050470

Sierra, L.A., Pellicer, E., Yepes, V., 2017. Method for Estimating the Social Sustainability of Infrastructure Projects. Environ. Impact Assess. Rev 65, 41-53. https://doi.org/10.1016/j.eiar.2017.02.004

Sierra, L.A., Pellicer, E., Yepes, V., 2015. Social Sustainability in the Lifecycle of Chilean Public Infrastructure. J. Constr. Eng. Manag. 142, 05015020. https://doi.org/10.1061/(ASCE)CO.19437862.0001099 .

Sierra, L.A., Yepes, V., García-Segura, T., Pellicer, E., 2018a. Bayesian Network Method for DecisionMaking about the Social Sustainability of Infrastructure Projects. J. Clean. Prod. 176, 521-534. https://doi.org/10.1016/j.jclepro.2017.12.140

Sierra, L.A., Yepes, V., Pellicer, E., 2018b. A Review of Multi-Criteria Assessment of the Social Sustainability of Infrastructures. J. Clean. Prod. 187, 496-513. https://doi.org/10.1016/j.jclepro.2018.03.022

Sourani, A., 2008. Realising Sustainable Construction through Procurement Stratergies. Loughborough University.

Sourani, A., Sohail, M., 2011. Barriers to Addressing Sustainable Construction in Public Procurement Strategies. Eng. Sustain. ES4, 229-237. https://doi.org/http://dx.doi.org/10.1680/ensu.2011.164.4.229 
Sourial, N., Wolfson, C., Zhu, B., Quail, J., Fletcher, J., Karunananthan, S., Bandeen-Roche, K., Béland, F., Bergman, H., 2010. Correspondence Analysis is a Useful Tool to Uncover the Relationships among Categorical Variables. J Clin Epidemiol 63, 281-294. https://doi.org/10.1016/j.jclinepi.2009.08.008.

SPAG, 2012. Social Procurement in NSW: A Guide to Achieving Social Value through Public Procurement., Social Procurement Action Group, Sydney, Australia.

Stanford, M., Molenaar, K., Sheeran, K., 2016. Application of Indefinite Delivery-Indefinite Quantity Construction Strategies at the Federal Level. J. Manag. Eng. 32, 4016011. https://doi.org/10.1061/(ASCE)ME.1943-5479.0000437

Sutherland, V., Mctier, A., Glass, A., Mcgregor, A., 2015. Analysis of the Impact and Value of Community Benefit Clauses in Procurement, Training and Employment Research Unit (TERU). Glasgow: University of Glasgow. Svensson.

Sutterlüty, A., Šimunović, N., Hesser, F., Stern, T., Schober, A., Schuster, K.C., 2018. Influence of the Geographical Scope on the Research Foci of Sustainable Forest Management: Insights from a Content Analysis. For. Policy Econ. 90, 142-150. https://doi.org/10.1016/j.forpol.2018.02.003

Tam, C.M., Tam, V.W.Y., Tsui, W.S., 2004. Green Construction Assessment for Environmental Management in the Construction Industry of Hong Kong. Int. J. Proj. Manag. 22, 563-571. https://doi.org/10.1016/j.ijproman.2004.03.001

Taylor, P., Serpell, A., Kort, J., Vera, S., 2013. Awareness , Actions , Drivers and Barriers of Sustainable Construction in Chile. Technol. Econ. Dev. Econ. 19, 272-288. https://doi.org/10.3846/20294913.2013.798597

Testa, F., Annunziata, E., Iraldo, F., Frey, M., 2016a. Drawbacks and Opportunities of Green Public Procurement : An Effective Tool for Sustainable Production. J. Clean. Prod. 112, 1893-1900. https://doi.org/10.1016/j.jclepro.2014.09.092

Testa, F., Grappio, P., Gusmerotti, N.M., Iraldo, F., Frey, M., 2016b. Examining Green Public Procurement Using Content Analysis: Existing Difficulties for Procurers and Useful Recommendations. Environ. Dev. Sustain. 18, 197-219. https://doi.org/10.1007/s10668-015-9634-1

Tsai, C.Y., Chang, A.S., 2012. Framework for Developing Construction Sustainability Items : the Example of Highway Design. J. Clean. Prod. 20, 127-136. https://doi.org/10.1016/j.jclepro.2011.08.009

Ugwu, O.O., Haupt, T.C., 2007. Key Performance Indicators and Assessment Methods for Infrastructure Sustainability — a South African Construction Industry Perspective. Build. Environ. 42, 665-680. https://doi.org/10.1016/j.buildenv.2005.10.018

Ugwu, O.O., Kumaraswamy, M.M., Wong, A., Ng, S.T., 2006. Sustainability Appraisal in Infrastructure Projects ( SUSAIP ) Part 1 . Development of Indicators and Computational Methods. Autom. Constr. 15, 239-251. https://doi.org/10.1016/j.autcon.2005.05.006

UNEP, 2013. Sustainable Public Procurement: A Global Review.

UNEP, 2009. Guidelines for Social Life Cycle Assessment of Products, United Nations Environment Programme. París. https://doi.org/DTI/1164/PA 
UNESCO, 2017. Understanding Sustainable Development. Retrieved [WWW Document]. URL www.unesco.org (accessed 7.7.16).

United Nations, 2008. Public Procurement as a Tool for Promoting more Sustainable Consumption and Production patterns [WWW Document]. Sustain. Dev. Innov. Briefs August. URL https://sustainabledevelopment.un.org/content/documents/no5.pdf (accessed 10.4.16).

Valdes-Vasquez, R., Klotz, L.E., 2013. Social Sustainability Considerations during Planning and Design: Framework of Processes for Construction Projects. J. Constr. Eng. Manag. 139, 80-89. https://doi.org/10.1061/(ASCE)CO.1943-7862.0000566

Veeravigrom, M., Muench, S.T., Kosonen, H., 2015. A Global Framework for Sustainable Roadway Rating Systems, in: In TRB 94th Annual Meeting Compendium of Papers, Washington DC, United States, 2015.

Walker, H., Brammer, S., 2012. The Relationship between Sustainable Procurement and E-Procurement in the Public Sector. Intern. J. Prod. Econ. 140, 256-268. https://doi.org/10.1016/j.ijpe.2012.01.008

Walker, H., Brammer, S., 2009. Sustainable Procurement in the United Kingdom Public Sector. Supply Chain Manag. An Int. J. 14, 128-137. https://doi.org/10.1108/13598540910941993

Walker, H., Miemczyk, J., Johnsen, T., Spencer, R., 2012. Sustainable Procurement: Past, Present and Future. J. Purch. Supply Manag. 18, 201-206. https://doi.org/10.1016/j.pursup.2012.11.003

Whang, S.-W., Kim, S., 2015. Balanced Sustainable Implementation in the Construction Industry: The Perspective of Korean Contractors. Energy Build. 96, 76-85. https://doi.org/10.1016/j.enbuild.2015.03.019

Winter, S., Lasch, R., 2016. Environmental and Social Criteria in Supplier Evaluation - Lessons from the Fashion and Apparel Industry. J. Clean. Prod. 139, 175-190.

Wright, T., 2015. New Development: Can “Social Value” Requirements on Public Authorities Be Used in Procurement to Increase Women's Participation in the UK Construction Industry? Public Money Manag. ISSN 35, 135-140. https://doi.org/10.1080/09540962.2015.1007708

Xia, B., Chan, A., Molenaar, K., Asce, M., Skitmore, M., 2012. Determining the Appropriate Proportion of Owner-Provided Design in Design-Build Contracts : Content Analysis Approach 138, 10171022. https://doi.org/10.1061/(ASCE)CO.1943-7862.0000522.

Xia, B., Chan, A., Zuo, J., Molenaar, K., 2013. Analysis of Selection Criteria for Design-Builders through the Analysis of Requests for Proposal. J. Manag. Eng. 29, 19-24. https://doi.org/10.1061/(ASCE)ME.1943-5479.0000119

Xia, B., Skitmore, M., Wu, P., Chen, Q., 2014. How Public Owners Communicate the Sustainability Requirements of Green Design-Build Projects. J. Constr. Eng. Manag. 140, 04014036. https://doi.org/10.1061/(ASCE)CO.1943-7862.0000879.

Yigitcanlar, T., Dur, F., 2010. Developing a Sustainability Assessment Model: The Sustainable Infrastructure, Land-Use, Environment and Transport Model. Sustainability 2, 321-340. https://doi.org/10.3390/su2010321

Yildirim, U., Başar, E., Uğurlu, Ö., 2017. Assessment of Collisions and Grounding Accidents with 
Human Factors Analysis and Classification System (HFACS) and Statistical Methods. Saf. Sci. https://doi.org/10.1016/j.ssci.2017.09.022 